\title{
PANORAMA DO DIREITO CIVIL BRASILEIRO: DAS ORIGENS AOS DIAS ATUAIS
}

\author{
José Carlos Moreira Alves \\ Professor Titular de Direito Civil da Faculdade de Direito da USP \\ Ministro do Supremo Tribunal Federal
}

Resumo:

$\mathrm{O}$ artigo principia com a análise das origens do direito civil brasileiro, e para tanto faz um breve histórico do antigo direito civil lusitano.

A seguir trata do nosso direito civil no período da Independência até a entrada em vigor do Código Civil em 1917, procurando fazer uma abordagem histórica das propostas ao mesmo, examinando em especial a Consolidação das Leis Civis de Teixeira de Freitas, entre outras tentativas.

Passa a analisar na seqüência o Código Civil de Clóvis Bevilaqua, sua introdução e a divisão das matérias, para posteriormente fazer algumas observações sobre as alterações e inovações introduzidas pela legislação posterior.

Finaliza discorrendo sobre as propostas de reforma ao mesmo, através das três tentativas feitas no passado e lembrando ainda a existência de uma quarta em curso.

Abstract:

The article begins with the analysis of the origins of Brazilian Civil Law, and for that it goes into a brief history of the old Portuguese Civil Law.

It then speaks about our Civil Law in the period of Independence until the Civil Code of 1917 came into effect, trying to deal from an historical point of view with the proposals to this Code, paying special attention to the Consolidação das Leis Civis de Teixeira de Freitas (The Consolidation of Civil Laws, by Teixeira de Freitas), among other attempts.

It analyzes then the Civil Code of Clovis Bevilaqua, its introduction and its division of subjects, to afterwards make some observations on the changes and innovations introduced by later legislation.

It finishes discoursing on the proposals of reform of this Code, through three attempts made in the past and reminding us of a fourth attempt under way. 


\section{Sumário:}

1. As origens do direito civil brasileiro.

2. Da independência ao Código Civil.

3. O Código Civil.

4. Alterações e inovações introduzidas pela legislação posterior ao Código Civil.

5. Os movimentos de reforma do Código Civil.

\section{AS ORIGENS DO DIREITO CIVIL BRASILEIRO.}

O direito civil brasileiro deita suas rázes no antigo direito civil português, ligando-se a este mais estreitamente do que o próprio direito civil lusitano dos tempos modernos.

Daí, sua formação profundamente romanística.

Pouco depois da proclamação da independência do Brasil, editouse a Lei de 20 de outubro de 1823 , em que se preceituou que permaneceriam vigentes as Ordenações, leis, regimentos, alvarás, decretos e resoluções promulgados pelos reis de Portugal até 25 de abril de 1821, enquanto não se organizasse um novo Código, ou não fossem eles alterados.

As normas de direito civil que então vigoravam em nosso país se encontravam principalmente no Livro IV das Ordenações Filipinas, de 1603.

Eram elas o resultado de uma longa evolução, que partira do período, já longínqüo, da reconquista da Península Ibérica aos mouros, quando ali se observavam, como fontes de direito, de um lado, o Código Visigótico também denominado Lex Gothorum, Liber Judicialis, Forum Judicum, designação esta que, na tradução que se fizera por ordem de Fernando III, se vertera por Fuero Juzgo -, e, de outro, direito costumeiro (mos, consuetudo, forum), que se integrava, sobretudo, por usos de origem romana vulgar, germânica, canônica e muçulmana, reduzidos a escrito nos estatutos municipais os força -, a partir dos fins do século XIII.

O Código Visigótico, em sua forma conhecida como vulgata, era, na legislação bárbara, o que mais influência recebera do direito romano, mas influência românica pré-justinianéia, porque oriunda do direito romano pósclássico anterior a Justiniano. No direito costumeiro, ao lado dos elementos canônicos e germânicos, destacavam-se os romanos, advindos do que 
modernamente se chama direito romano vulgar, o direito vivo, da época pósclássica, em que, por causa da decadência da cultura jurídica, se tornou mais nítida a divergência entre o direito oficial e o direito aplicado na prática, e a preponderância deste foi de tal ordem que acarretou alterações naquele, dando margem ao que se pode caracterizar como recepção da prática pelo direito oficial.

No século XIII, ocorre em Portugal o mesmo fenômeno que se verificou, embora em épocas diversas, em vários dos países europeus: a recepção do direito romano, cujo estudo ressurgira, na Itália, com os glosadores.

Em Portugal, essa recepção se dá por meio dos portugueses que foram estudar na Itália. E sua difusão se deve, principalmente, à universidade fundada, em 1290, por D. Dinis, em Lisboa, e, mais tarde, transferida para Coimbra.

A par do ressurgimento do direito romano, há o movimento de renovação do direito canônico, com a organização de novas coleções legislativas, a iniciar do Decreto de Graciano, as quais, no século XVI, seriam reunidas no que se denominou Corpus Juris Canonici, em paralelismo com o Corpus Juris Civilis. Essa renovação surgida no século XII, não tarda a refletir-se em Portugal.

A recepção do direito romano e os reflexos da renovação do direito canônico não conseguem, porém, afastar a utilização dos princípios costumeiros de origem diversa, como os germânicos. Mas é inegável que elas favorecem e isso porque o fortalecimento da autoridade do rei é conseqüência de princípios evidenciados no estudo do Corpus Juris Civilis - o desenvolvimento da atividade legiferante dos monarcas portugueses. Editam-se, assim, as leis gerais, que viriam, no período seguinte, já em pleno século $\mathrm{XV}$, a ser incorporadas nas Ordenações Afonsinas.

Essas Ordenações tiveram a elaboração concluída em 1446. Em sua feitura, foram utilizadas fontes anteriores, como leis gerais (muitas delas reunidas em duas antigas coleções - o Livro das Leis e Posturas e as Ordenações de D. Duarte), resoluções régias, concordatas e costumes nacionais ou de determinada cidade. Freqüentes os empréstimos e as alusões ao direito romano e ao direito canônico.

No século XVI, foram substituídas as Ordenações Afonsinas pelas Manuelinas, que as reformaram e as puseram em dia. Menos de século depois, em 1603, surgiram as Ordenações Filipinas, que, ditadas pela necessidade de 
atualização das Ordenações Manuelinas em face das inúmeras leis extravagantes que se lhes seguiram, conservaram, apesar de feitas sob o domínio espanhol, caráter nitidamente português.

A romanização do direito português muito deve a essas três Ordenações, quer pelo seu conteúdo, quer por suas extensas lacunas, principalmente na disciplina do direito civil.

Com efeito, se grande parte dos princípios nelas inseridos foram tomados de empréstimo ao direito romano, ou, pelo menos, neste inspirados, suas lacunas não tiveram papel menor na incorporação das regras romanas ao direito luso. Isso se deveu à utilização das fontes subsidiárias para o preenchimento dessas lacunas. Já as Ordenações Afonsinas estabeleciam que nos casos não disciplinados pelas leis do Reino, pelos estilos da Corte, ou pelos costumes, aplicar-se-iam as leis imperiais (direito romano) ou, em matéria que envolvesse pecado, os sagrados cânones (direito canônico); e, na ausência de norma romana ou canônica, mister seria que se observassem as glosas de Acúrsio, e, na insuficiência destas, as opiniões de Bártolo, ainda que delas dissentissem os demais doutores. Nesse sistema de fontes subsidiárias, foram introduzidas duas alterações pelas Ordenações Manuelinas: as leis imperiais (o direito romano) somente se deviam guardar pela boa-razão em que eram fundadas, e as glosas de Acúrsio e as opiniões de Bártolo não deveriam ser aplicadas se contrárias ao entendimento comum dos doutores. A propósito, nada se modifica nas Ordenações Filipinas.

Como nessas fontes subsidiárias avultava o direito romano, foi este largamente utilizado em Portugal até a segunda metade do século XVIII, e não apenas serviu para preencher as lacunas do direito português, mas também pelo prestígio de que desfrutava como ratio scripta, foi usado, com bastante freqüência, contra textos expressos das Ordenações, generalizando o entendimento de que as normas do direito lusitano que lhe fossem contrárias deveriam ser interpretadas restritivamente, ao passo que as com ele conformes seriam extensivamente compreendidas.

Foi o iluminismo que, a partir da segunda metade do século XVIII, se contrapôs ao uso abusivo do direito romano, que dominava a praxe forense portuguesa. 
A reação em favor do direito lusitano se iniciou com o Marquês de Pombal, e encontrou sua consagração legislativa na Lei de 18 de agosto de 1769, que ficou conhecida como a Lei da Boa-Razão.

Nas Ordenações Manuelinas e Filipinas, havia uma restrição ao direito romano como fonte subsidiária: as leis imperiais só se deviam guardar pela boa-razão em que eram fundadas. Omitiam-se, porém, ambas essas Ordenações quanto ao sentido dessa expressão.

Nos mais de cento e cinqüenta anos que medeiam entre as Ordenações Filipinas e a Lei da Boa-Razão, tanta foi a força que ganhou o direito romano que Luiz Antonio Verney, em 1746, criticando os estudos jurídicos em Portugal na primeira metade do século XVIII, exclamava:

"Sem dúvida, é digno de admiração que saiam os homens das Universidades falando muito nas leis de Justiniano, que só servem faltando a lei municipal, $e$ nada saibam daquela lei por que se hão de governar!"."

A Lei de 18 de agosto de 1769 (Lei da Boa-Razäo) alterou as normas de emprego das fontes subsidiárias, e, por isso, exerceu decisiva influência no campo do direito privado, onde mais intensamente se fazia mister a integração das lacunas. Ela proibiu a utilização de textos ou de autores se houvesse preceito das Ordenações, de leis extravagantes ou de usos do Reino, e determinou que o direito romano só se aplicasse quando conforme a boa-razão que era a recta ratio do jusracionalismo buscada nos textos que dela não se houvessem apartado e nas normas do direito das gentes observadas unanimemente pelos povos civilizados, recorrendo-se, em matéria política, econômica, mercantil e marítima, às leis das modernas nações cristãs. Complementaram-na os novos Estatutos da Universidade de Coimbra, que, a par de introduzirem radical reforma no ensino jurídico, forneceram critério prático para se aferir a conformidade do direito romano com a boa-razão: era o acolhido pelos mais ilustres representantes do usus modernus pandectarum. Essa inovação acarretou profundas alterações no direito privado português, por via de

1. Verdadeiro método de estudar, in Estudos médicos, jurídicos e teológicos, Lisboa, Sá da Costa, 1952, v. 4, p. 195. 
interpretação ou de leis novas. Por considerarem em desconformidade com a reta razão a regra romana nemo pro parte testatus pro parte intestatus decedere potest (que se tinha implícita no direito português, pois as Ordenações admitiam o contrário, a título de privilégio, para os soldados), os jusnaturalistas a repeliram, sustentando que o princípio não fora acolhido pelo direito português, porque, para tanto, se fazia necessário fosse ele expressamente referido nas Ordenações, o que não ocorria. E reformas legislativas, igualmente inspiradas em idéias jusnaturalistas, revogaram princípios romanos tradicionais do direito luso. Evidenciam-no as diversas leis pombalinas, editadas nos meados do século XVIII, sobre o direito sucessório. Nelas, exalta-se a sucessão legítima como a forma sucessória compatível com a razão humana, estabelecendo-se, por isso, várias e drásticas restrições à sucessão testamentária. Subverte-se o princípio romano de que, para o herdeiro entrar na posse dos bens do de cuius, era preciso que deles se apossasse, introduzindo-se o instituto germânico da saisine, pelo qual a posse dos bens hereditários se transmitia automaticamente aos herdeiros.

Esse movimento se acirraria com a implantação, ocorrida no primeiro quartel do século XIX, do liberalismo em Portugal. Para essa exacerbação, concorriam diversas circunstâncias: a difusão das idéias liberais, a exaltação do individualismo, a adoção de princípios jurídicos inspirados nessa nova ordem de coisas e constantes das codificações mais recentes.

Tudo isso explica a razão por que recrudesce, a partir de 1820 , tendência que já se observava em Manuel de Almeida Souza ${ }^{2}$ : como direito subsidiário se vão deixando de lado as doutrinas romanas dos autores do usus modernus pandectarum, para invocarem-se, cada vez mais freqüentemente, os princípios das modernas codificações européias que, muitas vezes, se afastavam daquelas doutrinas.

Nesse momento, porém, o Brasil proclamava sua independência, desligando-se de Portugal.

2. Esse autor já invocava, em suas obras, o Código Fredericiano (da Prússia, de 1749), o de Napoleāo e o Civil da Sardenha. 


\section{DA INDEPENDÊNCIA AO CÓDIGO CIVIL.}

Foi em virtude de a mencionada Lei de 20 de outubro de 1823 haver estabelecido que permanecia vigente a legislação portuguesa promulgada até 25 de abril de 1821, que não se aplicaram ao Brasil as reformas que o liberalismo, a partir do começo da década de vinte passou a introduzir em Portugal, movido, principalmente, pelos novos preceitos das legislações estrangeiras que começavam a multiplicar-se e que eram diversos da tradição romana do direto lusitano. De outra parte, a intensidade da influência das idéias que tinham seu nascedouro na Revolução Francesa era muito maior num país como Portugal, vizinho de suas fontes, do que no Brasil, apartado delas pela distância de um oceano, e absorvido pelos problemas graves da consolidação de sua independência.

A esse fator estático iria, em breve, adicionar-se um fator dinâmico: a atuação, no campo legislativo, de Teixeira de Freitas, com a elaboração, em 1857, da Consolidação das Leis Civis, e, posteriormente, com a redação, que ficou inacabada, do Esboço, que era o Projeto de Código Civil que o Governo Imperial lhe encomendara.

A Constituição Imperial de 1824, no art. 179, XVIII, estabelecia:

"Organizar-se-á, quanto antes, um Código Civil e um Criminal, fundados nas sólidas bases da justiça e da equiidade".

Em 1830, cumpriu-se parcialmente o preceituado nesse dispositivo: promulgou-se o Código Criminal do Império Brasileiro. Mas, quase um século precisaria decorrer para que se elaborasse o outro dos códigos, que, na linguagem pitoresca da Constituição, deveriam ser organizados $o$ quanto antes o Código Civil.

O primeiro passo para a feitura do Código Civil foi a contratação (celebrada em 15.2.1855) de Teixeira de Freitas para realizar, como obra preparatória, a Consolidação das Leis Civis. Anteriormente, Eusébio de Queiroz $^{3}$ sugerira que se adotasse como Código Civil o Digesto Português, de 
autoria de Corrêa Telles, ${ }^{4}$ sugestão que morreu no nascedouro, repudiada que foi pelo Instituto da Ordem dos Advogados.

Em três anos, concluía Teixeira de Freitas essa Consolidação que, em 1897, seria traduzida, em resumo, para o francês, por Raul de La Grasserie. ${ }^{5}$

A Consolidação das Leis Civis pôs ordem no caos dos princípios civis constantes das Ordenações Filipinas e das leis extravagantes, permitindo saber quais as normas que vigoravam no território brasileiro. $\mathrm{O}$ ponto mais alto desse trabalho se situa nas duas centenas de páginas em que se desdobra a Introdução que o acompanha. Nela, distingue Teixeira de Freitas, na execução a que se propôs, a parte prática da parte científica. Na parte prática, pela natureza mesma da obra consolidar as regras de direito civil em vigor, reduzindo-as a preceitos tão concisos quanto possível -, o trabalho dependia de erudição, paciência e fidelidade, não dando azo a criações. Estas só encontrariam campo na parte teórica, na demarcação dos limites da Legislação Civil e no sistema de sua exposição. E na sistemática da Consolidação Freitas revela, de modo inequívoco, o seu espírito criador. $O$ sistema que adota, após submeter a exaustiva crítica o das Institutas romanas pessoas, coisas e ações -, e os modernos, desde o de Leibniz até o dos romanistas alemães representados por Mackeldey, é assim exposto por ele:

"Sob as idéias fundamentais, que temos desenvolvido, a Consolidação das Leis Civis apresenta em sua primeira divisão duas grandes categorias, que formam a sua Parte Especial. A essa Parte Especial antecede uma Parte Geral, que lhe serve de prolegômenos.

A Parte Geral trata em dois Títulos das 'pessoas' $e$ das 'coisas', que são os elementos constitutivos de todas as relações jurídicas, e portanto das relaçōes jurídicas na esfera do Direito Civil.

4. Digesto português ou Tratado dos direitos e obrigaçōes civis acomodado às leis e costumes da nação portuguesa para servir de subsídio ao novo código civil, Lisboa, Clássica, 1909, 3 vs.

5. Code civil du Venezuela; lois civiles du Brésil, V. Giard \& E. Brière, Paris, 1897. 
A Parte Especial compõe-se de dois Livros, em correspondência com a fundamental divisão das duas categorias. $O 1^{Q}$ Livro tem por objeto os 'direitos pessoais', o $2^{o}$ Livro - os 'direitos reais"' 6

Pela primeira vez, em legislação civil, adotava-se a sistemática alemã, utilizada nas obras dos pandectistas, da divisão em parte geral, onde se reuniam os elementos constitutivos do direito subjetivo, e em parte especial, onde se colocavam as regras referentes aos direitos subjetivos em espécie. Mas, na subdivisão de ambas se afastava da orientação germânica: na parte geral, adstringia-se as pessoas e as coisas, excluindo os fatos jurídicos, por entender que só os fatos voluntários lícitos os atos jurídicos é que precisavam de ser disciplinados, razão por que "a matéria dos fatos deixa de ser geral, e pertence quase toda às matérias especiais dos contratos e testamentos", havendo muitos direitos "que nada têm com esses atos jurídicos, ao passo que sem pessoas $e$ coisas, e ao menos sem pessoas, não há direito algum"; 8 e na parte especial se limitava a distinguir os direitos pessoais dos direitos reais, divisão que se the afigurava fundamental no tocante aos direitos subjetivos, considerando que a adotada por Mackeldey direito das coisas, direito das obrigações, direito de família, direito das sucessões e concurso de credores - pecava por desnecessária abundância. Para enquadrar os diferentes direitos numa dessas duas categorias, caracterizava os direitos reais como "todos os direitos absolutos, que imediatamente recaem sobre as coisas, ou em unidade complexa, formando o direito de domínio ou propriedade material; ou em unidade elementar, e distribuídos por dois ou mais agentes", e os direitos pessoais como "os que afetam uma ou mais pessoas individualmente obrigadas, e só por intermédio destas recaindo sobre as coisas". 9 Por isso, no concernente aos direitos pessoais, dividiaos em direitos pessoais nas relações de família (que abarcavam o casamento, o

6. Consolidação das leis civis, Rio de Janeiro, Tipografia Universal de Laemmert, 1857, p. XCIX e C.

7. Ibidem, p. CVII.

8. Ibidem, p. CVII e CVIII.

9. Ibidem, p. C e CI. 
pátrio poder, o parentesco, as tutelas e as curatelas) e direitos pessoais nas relaçōes civis (que abrangiam as causas produtoras deles - os contratos e os delitos e as causas de sua extinção); e, nos direitos reais, enquadrava o domínio, a servidão, a herança, a hipoteca e a prescrição aquisitiva (a usucapio). Reconhecia, porém, Teixeira de Freitas que essa distribuição de matérias não era a que se lhe afigurava a melhor, admitindo seu aperfeiçoamento se se tratasse de codificação nova, onde pudesse "escolher materiais à vontade" ${ }_{10}^{10} \mathrm{E}$ observava que a herança apresentava natureza comum às duas espécies de direitos subjetivos, devendo entrar em ambas; o mesmo acontecia com o concurso de credores e com a prescrição, o que conduzia à necessidade de um terceiro livro na parte especial, onde se contivessem as disposições comuns aos direitos reais e aos direitos pessoais, e que se dividiria em três títulos: o 10, concernente à herança; o $2^{\circ}$, ao concurso de credores; e o $3^{\circ}$, à prescrição.

Se a preservação, em nosso direito, das antigas tradições jurídicas portuguesas, hauridas, precipuamente, nas fontes romanas, muito deve à Consolidação das Leis Civis, que foi o obstáculo maior à utilização de elementos estranhos para o preenchimento de lacunas muitas vezes inexistentes, e, portanto, à introdução de princípios alienígenas contrários à nossa formação jurídica, é no Esboço ao Código Civil que o espírito criador de Teixeira de Freitas encontra terreno propício para evidenciar-se.

Em 1858, decreto de 22 de dezembro autorizou o Ministro e Secretário de Estado dos Negócios da Justiça a contratar um jurisconsulto de sua escolha para a elaboração do Projeto de Código Civil do Império brasileiro. E o escolhido foi Teixeira de Freitas, que, em 11 de janeiro de 1859, se compromete, em contrato firmado com o Governo, a entregar o projeto até 31 de dezembro de 1861. Posteriormente, dilatou-se esse prazo para 30 de junho de 1864.

Entendeu Teixeira de Freitas que deveria elaborar, antes do Projeto definitivo, um esboço, e deste já estavam impressos 4.908 artigos, quando seu autor, convencendo-se de que se impunha a unificação do direito privado (reunindo-se, assim, as normas de direito civil e de direito comercial), se dirigiu ao então Ministro da Justiça, o Conselheiro Martim Francisco Ribeiro de Andrade, e propôs que se alterasse o plano da codificação, elaborando-se ao 
invés de um Código Civil, dois Códigos: o Código Geral (onde se trataria das causas jurídicas, das pessoas, dos bens, dos fatos e dos efeitos jurídicos) e o Código Civil (que abrangeria os efeitos civis, os direitos pessoais e os direitos reais).

No ofício, datado de 20 de setembro de 1867 pouco mais de vinte e um anos antes da célebre aula inaugural que Cesare Vivante proferiu em Bolonha sobre a unificação do direito privado -, que Freitas endereçou ao Conselheiro Martim Francisco Ribeiro de Andrade, lêem-se trechos como este:

"O Governo espera por um Projeto do Código Civil no sistema desse Esboço, sistema traçado no meu contrato de 10 de janeiro de 1859, e para mim já não há possibilidade de observar tal sistema, convencido como estou, de que a empresa quer diverso modo de execução.

O Governo quer um Projeto de Código Civil para reger como subsídio ao complemento de um Código do Comércio; intenta conservar o Código Comercial existente com a revisão, que lhe destina; e hoje minhas idéias são outras, resistem invencivelmente a essa calamitosa duplicação de Leis Civis, não distinguem no todo das Leis desta classe algum ramo, que exija um Código do Comércio". ${ }^{11}$

E, mais adiante:

"Não há tipo para essa arbitrária separação de Leis, a que deu-se o nome de Direito Comercial ou Código Comercial; pois que todos os atos da vida jurídica, excetuados os benefícios, podem ser comerciais ou não comerciais, isto é, tanto podem ter por fim 
o lucro pecuniário, como outra satisfação da existência.

Entretanto, a inércia das legislações, ao inverso do progressivo desenvolvimento das relações jurídicas, formou lentamente um grande depósito de usos, costumes e doutrinas, que passaram a ser Leis de exceção, e que de Leis passaram a ser Códigos, com seus tribunais de jurisdição restrita e improrrogável. Eis a história do Direito Comercial! Eis falsificada a instrução jurídica, e aturdidos os espiritos com a frivola anatomia dos atos até extrair-lhes das entranhas o delicado critério!".12

Era a primeira vez que alguém não se limitava a criticar, de maneira vaga como antes o fizeram, na Itália, Montanelli ${ }^{13}$ e Pisanelli, ${ }^{14} \mathrm{e}$, no Brasil, Pimenta Bueno ${ }^{15}$, a dicotomia direito civil-direito comercial, mas defendia, propondo-se a efetivá-la em projeto de código, a tese da unificação do direito privado, por estar convencido de que não havia diferença substancial que justificasse a separação.

A proposta de Teixeira de Freitas obteve parecer favorável da Seção de Justiça do Conselho de Estado, mas não mereceu aprovação do Governo Imperial e, em 1872 depois da negativa formal de Teixeira de Freitas de ultimar o Esboço de Projeto de Código Civil, por estar convencido da necessidade dos dois Códigos que propusera -, foi rescindido o contrato por ele firmado com o Governo. Mas, a idéia estava lançada, e, no futuro, iria alastrarse.

O sistema adotado por Teixeira de Freitas no Esboço se afasta do por ele seguido na Consolidação das Leis Civis.

12. Ob. cit., p. 269.

13. Introduzione filosofica allo studio del diritto commerciale positivo, cap. 13 e 14 .

14. Commentario del codice di procedura civile: della competenza, v. 1, parte 1, n. 12, p. 23.

15. Direito público brasileiro e análise da Constituição do Império, Rio de Janeiro, 1958, p. 11. 
Assim, na parte geral, acrescentou às pessoas e às coisas, os fatos, e o justificou desta forma:

"Esta Seçāo 3ạ, que trata dos fatos, um dos elementos dos direitos regulados no Código Civil, não estava em meu primitivo plano, como se pode ver na Consolid. das Leis Civis Introd., págs. 106, 107 e 108. Ali disse eu: 'alguns Escritores adicionam este terceiro elemento sob a denominação de fatos, fatos jurídicos, atos juridicos, de que também tratam na parte geral das matérias do Direito Civil. Não nos conformamos com este método'.

Hoje, ao contrário, estou convencido de que sem esse método será impossível expor com verdade a síntese das relaçōes do Direito Privado, e fugir a um defeito gravissimo de que se ressentem todos os Códigos, com exceção do da Prússia. Eles têm legislado sobre matéria de aplicação geral e quase todos os assuntos do Código Civil, do Código de Comércio e do Código do Processo, como se fossem exclusivamente aplicáveis só aos contratos e testamentos; e com este sistema embaraçam o exato conhecimento do Direito Privado, isolando fenômenos que são efeitos da mesma causa, e contribuindo destarte para que muitas espécies escapem à influência de seus princípios diretores".16

$\mathrm{Na}$ parte especial, além de adicionar um terceiro livro cujo conteúdo não chegou a elaborar -, referente às disposições comuns dos direitos reais e pessoais (herança, concurso de credores e prescrição), alterou a subdivisão do livro concernente aos "direitos pessoais", iniciando pelos "direitos pessoais em geral" (onde disciplinou, genericamente, a obrigação), prosseguindo com os "direitos pessoais nas relações de família" (onde se ocupou do direito de

16. Códiga civil: esboço, Rio de Janeiro, Ministério da Justiça e Negócios Interiores, 1952, v. 1 , nota ao art. 431, p. 229. 
familia) e concluindo com os "direitos pessoais nas relações civis" (onde regulou as causas das obrigaçôes); e, no livro dos direitos reais, tratou, primeiro, dos "direitos reais em geral", em seguida, dos "direitos reais sobre as próprias coisas" (o domínio e o condomínio), e, por último, dos "direitos reais sobre as coisas alheias" (enfiteuse, usufruto, uso, habitação e servidões).

Precedendo à própria parte geral, colocou um título preliminar: do "lugar" e do "tempo", no qual disciplinou os limites da aplicação espacial do Código Civil, e, após acentuar que, no tocante à sua aplicação no tempo, essa matéria seria objeto de lei especial transitória, estabeleceu normas sobre a contagem de prazos.

Mas não apenas na sistemática se afasta Teixeira de Freitas dos Códigos então conhecidos, especialmente do Código Civil francês, modelo de tantos que se lhe seguiram. Aparta-se deles, também, em pontos fundamentais, na disciplina dos diversos institutos jurídicos.

É especialmente na parte geral do Esboço que ressalta seu espírito inovador.

Distingue a capacidade de direito da capacidade de fato, e, quanto àquela, faz observação que só em tempos muito mais recentes se vai tornando correntia: a de que a capacidade de direito não se traduz pela aptidão de adquirir direitos, mas pelo grau dessa aptidão, e isso porque "não há pessoa sem capacidade de direito, por maior que fosse o número de proibiçōes do Código" ${ }^{17}$ É com base nisso que os civilistas modernos diferenciam a personalidade jurídica da capacidade de direito: aquela é conceito absoluto existe, ou não existe; esta, conceito relativo, existe em maior ou menor grau - é a medida da personalidade jurídica. Por outro lado, Freitas divide as pessoas em pessoas de existência visível (o homem) e pessoas de existência ideal, que também denomina pessoas jurídicas. Quanto às primeiras, reconhece-lhes a aptidão de adquirir todos os direitos civis, independentemente da qualidade de cidadão brasileiro e da

17. Ob. cit., nota ao art. 21, p. 24, onde se lê: "Grau de aptidão: não digo aptidão, porque não há pessoa sem capacidade de direito, por maior que fosse o número das proibições do Código. Desta maneira a capacidade de direito envolve sempre uma idéia relativa, mesmo em cada pessoa dada, visto que todas as pessoas são capazes de direito quanto ao que o Código não thes proíbe, e ao mesmo tempo incapazes de direito quanto ao que se lhes proibe". 
capacidade política; atribui-lhe existência desde a concepção, distanciando-se dos textos romanos que afirmavam que, durante a gestação, o filho ainda não era criatura humana, e optando pela solução do Código da Prússia, que preceituava: "os direitos comuns à humanidade pertencem aos filhos que não são ainda nascidos, a contar do momento de sua concepção", 18 no mesmo sentido, aliás, do direito das Ordenações Filipinas; para o nascimento, exige apenas a vida extrauterina, deixando de lado a vitalidade, à semelhança do Código prussiano e diferentemente do Código de Napoleão; a ausência vem disciplinada na parte geral, e não juntamente com o direito de familia; e, no tocante à comoriência, aparta-se do direito anterior, que se ajustava aos princípios do Corpus Iuris Ciuilis e do Código Civil francês, e estabelece que "quando não se possa saber qual delas faleceu primeiro, dever-se-á presumir que faleceram todas ao mesmo tempo, sem que se possa alegar transmissão de direitos entre elas". ${ }^{19}$ No que diz respeito às pessoas de existência ideal (as pessoas jurídicas), apresenta o Esboço, pela primeira vez numa codificação, a disciplina, sob todos os aspectos, desse instituto, o que mereceu de Freitas esta nota:

"Com algum receio apresento este Tít. 3o sobre as pessoas de existência ideal, não porque haja em meu espírito a mais leve sombra de dúvida, mas pela aparência de novidade, aliás meramente exterior, que apresenta uma sintese que até agora não se tem feito, $e$ sem a qual entretanto nāo se pode conhecer a teoria das pessoas, e toda a beleza e majestade do Direito Civil. Pela primeira vez tenta-se, e, o que é mais, em um Código, a temerária empresa de reunir em um todo o que há de mais metafisico em jurisprudência".20

Em matéria de coisas, depois de acentuar, no art. 317, que "todos os objetos materiais susceptiveis de uma medida de valor são coisas", as restringe

18. Ob. cit., nota ao art. 221, p. 135.

19. Ibidem, art. 243, p. 146.

20. Ibidem, nota ao art. 272, p. 158. 
às corpóreas no art. 319 ("Os objetos que, sendo susceptiveis de uma medida de valor não foram objetos materiais, também não se reputam coisas no sentido deste Código"), orientação que vários anos após seria, também, a do B.G.B., ao estabelecer, no § 90: "Coisas no sentido da lei sāo somente os objetos corpóreos" ${ }^{21} \mathrm{E}$ se afasta do direito romano ao excluir da categoria das coisas as res communes omnium hominum, pela consideração de que "os objetos materiais comuns e inexauriveis não são elemento de direito" 22

É, porém, na disciplina dos fatos jurídicos como fontes produtoras de direitos subjetivos que há, em terreno particularmente difícil, antecipações que merecem destaque. Não escapou a Teixeira de Freitas a distinção, a que aludira Savigny sem aprofundá-la, entre os atos jurídicos, com base no modo pelo qual operava a vontade: se dirigida diretamente ao nascimento ou à extinção da relação jurídica, "declaraçāo de vontade ou negócio jurídico"; se dirigida imediatamente a outros escopos, tendo o efeito jurídico posto secundário na consciência ou não sendo ele desejado, "atos jurídicos que não são negócios jurídicos", categoria que permaneceu inominada na obra de Savigny. Adotou-a Teixeira de Freitas, no Esboço. Após acentuar, no art. 435, que "os fatos voluntários, ou são atos lícitos, ou ilícitos" e que "são atos lícitos as ações voluntárias não proibidas por lei, de que possa resultar alguma aquisição, modificação, ou extinção de direito", refere, no art. 436, os atos lícitos que não têm por fim imediato a aquisição, modificação, ou extinção de direitos, mas que somente produzirão esses efeitos nos casos que na lei foram expressamente declarados, e, em seguida, alude, no art. 437, aos negócios jurídicos a que dá a denominação de atos jurídicos: "Quando os atos lícitos tiverem por fim imediato alguma aquisição, modificação, ou extinção de direitos, serão designados pela denominação de atos jurídicos" Em dois pontos se adiantava Freitas e Savigny: primeiro, porque este, ao aludir aos atos jurídicos que não eram negócios jurídicos, enquadrava neles atos lícitos e atos ilícitos; segundo, porque, enquanto Savigny apenas fazia a distinção, Freitas ressaltava claramente que os efeitos desses atos lícitos seriam somente os previstos na lei, o que só veio a ser

21. $\$ 90$. Sachen in Sinne des Gesetzes sind nur Körperliche Gegenstände.

22. Ob. cit, v. 1, nota ao art. 318, p. 193. 
evidenciado pela doutrina mais moderna, a partir do início do século $\mathrm{XX}$, com Manigk, ao basear a distinção entre negócios jurídicos e participaçōes de vontade na diferença entre efeitos ex uoluntate e efeitos ex lege. É admirável, no plano estrito do legislador, a intuição de Freitas em incluir no Esboço esse art. 436. Só recentemente, e 1967, é que o novo Código Civil português veio a ocupar-se deles, preocupando-se, porém, apenas em alertar que a tais atos são aplicáveis, na medida em que a analogia das situações o justifique, as normas do negócio jurídico. $\mathrm{E}$ cabe, ainda, assinalar que, no terreno movediço do negócio jurídico, não escapou a Freitas a existência do que a doutrina mais moderna denomina negócio de atuação, assim definido por Lorenzo Campagna: são os negócios jurídicos em que "a vontade não é declarada, mas somente expressa mediante atuação" ${ }^{23}$ No art. 446, já preceituava que os atos exteriores de manifestação de vontade podiam consistir "na execução de algum fato material, consumado ou começado", e não apenas na expressão positiva ou tácita da vontade. Quanto aos contratos, que o art. 438 refere como exemplo de atos jurídicos entre vivos, apressa-se Freitas em advertir que não adota o conceito amplíssimo que lhe deu Savigny, mas o restrito: o de contrato obrigatório. ${ }^{24}$

Na parte especial do Esboço, encontram-se anotações com alguma abundância na seção I ("Dos direitos pessoais em geral") do Livro segundo ("Dos direitos pessoais"), na qual se disciplina a parte geral das obrigações. Do exame dessas notas, porém, se verifica que, ao lado das em que Freitas expressa opiniões críticas com relação ao direito romano e à legislação e à doutrina de seu tempo, há inúmeras em que, ou se adstringe a citar textos romanos sem indicação de fonte, ou os cita com observações complementares. Não é, porém, difícil localizar, nas fontes romanas, os textos que Freitas, em apoio dos artigos que inclui no Esboço, transcreve sem qualquer indicação. Tomou-os, em sua quase totalidade, das citações feitas por Maynz, e das que se encontram em Molitor. ${ }^{25}$ As mais das orientações que acolhe são as romanas. Não poucas

23. I "negozi.de attuazione" e la manifestazione dell'intento negoziale, Milano, Giuffrè, 1958, p. 1.

24. Ob. cit., v. 1, nota ao art. 438 , p. 236.

25. Vide, a propósito, J. C. Moreira Alves, A formação romanística de Teixeira de Freitas e seu espírito inovador, in Augusto Teixeira de Freitas e il diritto latinoamericano, a cura de Sandro Schipani, Padova, Cedam, 1988, nota 51, p. 34. 
vezes, critica as soluções adotadas pelo Código Civil francês e que se contrapõem àquelas. Quando se afasta do direito romano, diz a razão de dele se haver apartado.

Já na seção II ("Direitos pessoais nas relações de familia") desse mesmo Livro segundo, regulam-se os esponsais e os pactos antenupciais, admitidos também no direito anterior. ${ }^{26}$ Disciplina-se a celebração do casamento em face da Igreja Católica, bem como os matrimônios mistos autorizados, ou não, por ela. ${ }^{27} \mathrm{O}$ regime legal de bens é o que vem do direito português: o da comunhão universal. Ao lado dele, regulam-se os regimes da separação e o dotal. O divórcio não é o romano, mas o canônico: a separação de pessoas e de bens, sem dissolução do vínculo matrimonial. ${ }^{28}$ Permite-se, porém, a dissolução do casamento celebrado sem autorização da Igreja Católica, se convertido o cônjuge não-cristão ou não-católico, este casar-se com outrem perante aquela Igreja. ${ }^{29}$ Segue-se o princípio romano impeditivo da turbatio sanguinis, com a extensão que teve no período pós-clássico, uma vez que se exige, para passar-se ao segundo casamento, a observância do prazo mínimo de dez meses, qualquer que seja a causa da dissolução do primeiro matrimônio. ${ }^{30}$ Aos filhos que tenham domicilio de origem no Brasil só se permite a legitimação pelo subseqüente casamento. ${ }^{31}$ Proíbe-se o reconhecimento dos filhos adulterinos, incestuosos e sacrílegos. ${ }^{32}$ Disciplina-se a adoção, admitida, também, no direito anterior. Regula-se, por fim, largamente, a tutela e a curatela. ${ }^{33}$

Na última seção (a III, "Dos direitos pessoais nas relações civis") do Livro segundo, encontram-se os preceitos sobre as obrigações derivadas dos

26. Arts. 1.237 a 1.253 .

27. Arts. 1.254 a 1.298 .

28. Art. 1.379 .

29. Art. 1.420 , n. 2.

30. Art. 1.455 .

31. Art. 1.554.

32. Art. 1.601.

33. Arts. 1.634 a 1.829 . 
contratos, dos atos lícitos que não são contratos, dos atos involuntários, dos fatos que não são atos e dos atos ilícitos. Merece destaque, nessa parte do Esboço, a sistematização das matérias, especialmente no tocante aos preceitos relativos ao contrato em geral e aos referentes às obrigações derivadas de atos ou fatos que não contratos. Há, na disciplina de todas essas obrigações, principalmente quanto às de origem contratual, larga inspiração romana. Dela, porém, não raras vezes se aparta, mantendo princípios da tradição luso-brasileira, como sucede, por exemplo, no mandato, que implica necessariamente a representação convencional, como se vê do art. 2.853: "Haverá mandato, como contrato (art. 1.830), quando uma das partes se tiver obrigado a representar a outra em um ou mais atos da vida civil".

No derradeiro livro do Esboço que chegou a elaborar o referente aos direitos reais -, Freitas, na disciplina desses direitos, segue, em geral, as diretrizes do direito romano. Adota o sistema do numerus clausus. ${ }^{34}$ Distingue os direitos reais sobre coisas próprias (o domínio e o condomínio) dos direitos reais sobre coisas alheias (enfiteuse, usufruto, uso, habitação, servidões). No art. 3.707, separa os direitos reais "verdadeiros" (que existem quando quem os exercer tiver a todos os respeitos direito de exercê-los, ou os tiver legitimado por prescrição) dos direitos reais "putativos" (que ocorrem quando, pelo fato de seu exercício ou da posse com justo título, ou só pelo fato de seu exercício ou da posse, se presumir com direito de exercê-los quem os exercer). Regula, em seguida, a posse, e, aí, é manifesta a influência de Savigny e do Código da Prússia. Vários de seus artigos reproduzem parágrafos desse Código. Por vezes, a nomenclatura é análoga, mas o sentido diferente. É o que ocorre com a "simples detenção", com a "posse perfeita" e com a "posse imperfeita": a simples detenção como disciplina no Esboço, abarca não apenas os casos de detenção do Código da Prússia, mas também alguns de posse imperfeita (unvollständiger Besitz); e a distinção entre "posse perfeita" e "posse imperfeita", como estabelecida no Esboço, se assenta, principalmente, nos conceitos de "domínio perfeito" e de "domínio imperfeito" adotados por Freitas, o que não sucede com o vollständiger und unvollständiger Besitz, sendo que, ainda, a "posse imperfeita" abarca, também, as hipóteses de exercício de direito real sobre coisa alheia "exercível" 
pela posse. E, à semelhança do que se verifica no Código Prussiano, a disciplina da detenção e da posse, no Esboço, é muito minuciosa. Quanto à aquisição de direitos reais, observa Freitas a distinção romana entre o título e o modo de aquisição. Este, com relação às coisas móveis, é a tradição, ao passo que, no tocante aos imóveis inovação digna de realce -, é a transcrição no Registro Conservativo. ${ }^{35}$ No concernente ao domínio, distingue o perfeito (direito real perpétuo de uma só pessoa sobre uma coisa própria móvel ou imóvel com todos os direitos sobre sua substância e utilidade) do imperfeito (que é o direito real resolúvel, ou fiduciário, de uma só pessoa sobre uma coisa, que aliena somente seu domínio útil). ${ }^{36}$ Permite o usufruto de coisas fungíveis e o usufruto de créditos. ${ }^{37} \mathrm{E}$ a servidão de tirar água é o último instituto disciplinado pelo Esboço, na parte que chegou a ser publicada.

Embora não se tenha transformado no Código Civil brasileiro e não tenha sido concluído, o Esboço exerceu grande influência sobre o direito civil latino-americano, especialmente na elaboraçāo do Código Civil argentino, como se vê destas palavras de Enrique Martinez Paz, em Freitas y su influencia sobre el Código Civil argentino:

"A proporção exata de artigos com que contribuiu o Esboço para o nosso Código foi revelada, depois de uma prolixa e inteligente investigação, pelo doutor Lisandro Segovia. Se se considerarem os três mil e tantos artigos, que compreendem os três primeiros livros do Código argentino, únicos sobre os quais podia se fazer sentir a influência de Freitas, se verificaria que um terço deles, isto é, algo mais de mil artigos foram tomados quase textualmente" ${ }^{38}$

35. Art. 3.809.

36. Arts. 4.072 e 4.300 .

37. Arts. 4.652 a 4.662 .

38. Freitas y su influencia sobre el código civil argentino, Córdoba, (Rep. Arg.), Imprenta de la Universidad, 1927, p. LIV-LV. 
E a consideração que Velez Sarsfield - o autor do Projeto do Código Civil argentino tinha ao Esboço de Freitas é evidenciada nesta resposta que o primeiro deu a críticas de Alberdi:

"Mas o doutor Alberdi julgou acertado citar-me exemplos do Código francês, que equivocadamente acredita ter seguido o método das Institutas, e se engana sobre a preferência que dei ao senhor Freitas sobre Tronchet, Portalis, Maleville. O doutor Alberdi confessa que não conhece os trabalhos de legislador do senhor Freitas e parece convencido de que nada melhor possa existir que os jurisconsultos que formaram o código francês, tão criticados hoje pelos jurisconsultos da mesma nação. Pode perdoar-me que eu, depois de um sério estudo dos trabalhos do senhor Freitas, os considere somente comparáveis com os de Savigny". ${ }^{39}$

No mesmo ano de 1872, em que era rescindido o contrato entre Teixeira de Freitas e o Governo Imperial, dois acontecimentos se verificam no terreno das tentativas de elaboração do Código Civil brasileiro.

Ao primeiro se refere Clóvis Bevilaqua ${ }^{40}$ ao aludir a um Projeto de Código Civil brasileiro elaborado pelo Visconde de Seabra, autor do Projeto de que resultara o Código Civil português de 1867, dizendo que não sabia se ele que não fora publicado era um trabalho completo, pois, a respeito, só vira, na Secretaria da Justiça, um manuscrito com o título preliminar e alguns artigos sobre a capacidade civil e seu exercício. Maiores informações sobre esse Projeto se encontram na carta do Barão de Loreto ao Conselheiro Thomaz Ribeiro, escrita em 10 de agosto de 1895, e publicada em $O$ Direito, sob o título Projeto do Código Civil brasileiro pelo Visconde de Seabra. Em anotação a um trecho dessa carta, lê-se sobre o referido Projeto:

39. Ob. cit., p. LVI.

40. Código civil dos Estados Unidos do Brasil comentado, $9^{\mathrm{a}}$ ed., Rio de Janeiro, Francisco Alves, 1951, v. 1, p. 19. 
"Do trabalho acima indicado existe um exemplar manuscrito, feito com esmero caligráfico, $e$ encadernado em marroquim verde, 'in $8^{o}$ ' grande.

Nas duas faces da capa há, gravadas em ouro, as armas imperiais do Brasil; por baixo delas, na primeira face, a inscrição 'Pedro II', e, no verso, '1872'. Lề-se no frontispício: 'Código Civil Brasileiro Projeto Oferecido à sua Magestade o Imperador do Brasil por Antonio Luiz de Seabra - Natural do Rio de Janeiro. Cadete honorário do antigo regimento de linha de Minas Gerais e Oficial da Ordem da Rosa. - Alexandre Tavano fez a pena'.

O manuscrito compreende 392 artigos do projeto do Código. No fim da última página, a assinatura autógrafa do autor, e, na linha inferior, em letra minúscula, a data 5 de fevereiro de 1872 - $O$ dito exemplar pertence hoje à livraria do Sr. Marquês de Paranaguá". 41

Em 1951, a Revista da Faculdade de Direito da Universidade de Lisboa ${ }^{42}$ iniciou a publicação de manuscrito desse Projeto, dando, em nota, a seguinte explicação:

'A Revista da Faculdade de Direito de Lisboa regozija-se com o fato de poder reproduzir nas suas páginas o presente projeto (parcial) de Código Civil Brasileiro da autoria do Visconde de Seabra, que julga inédito e cujo manuscrito lhe foi amavelmente facultado, com autorização de publicação, pelo seu atual proprietário, o Exmo. Sr. Dr. Augusto Raul de Seabra, Juiz no Ultramar e descendente do glorioso autor do referido projeto".

41. O Direito, v. 68 (set./dez. 1895), nota 1, p. 319.

42. v. 8, p. 305-325. 
Essa publicação foi continuada nos volumes $9^{43}$ e $10 .^{44}$ Por ela se verifica que esse manuscrito, como o referido na nota à carta do Barão de Loreto, contém 392 artigos. Na sua última página, lê-se: "Fim da primeira parte". O Projeto que, segundo parece, ficou inacabado, apresenta um Título Preliminar (Da lei civil, seu objeto e natureza) e o Livro Único (Da capacidade civil e seu exercício) da Primeira Parte. Esse conteúdo corresponde ao do manuscrito que Clóvis Bevilaqua diz ter visto na Secretaria da Justiça.

O segundo acontecimento a que nos referimos foi, no final desse ano de 1872, a celebração, entre o Governo e o Senador Nabuco de Araújo, de contrato para a elaboração de novo Projeto de Código Civil. Não pode ele, no entanto, concluir esse empreendimento por ter sido surpreendido pela morte, em 1878. Do seu esforço, restaram 118 artigos do Título Preliminar (que contém disposições acerca da publicação, efeito e aplicação das Leis do Império do Brasil) e 182 da Parte Geral (que abarca, apenas, o Título I Das Pessoas - do Livro I Dos Elementos dos Direitos), os quais foram publicados postumamente, em 1882.45 Seu filho Joaquim Nabuco -, na biografia que escreveu sobre ele e que é obra clássica da literatura brasileira, revela ${ }^{46}$ que o pai deixou grande número de livros de notas relativos aos estudos que fez para o Projeto, mas de difícil inteligência para a aferição de seu pensamento por terceiros. A transcrição, porém, de uma delas, concernente às pessoas jurídicas, mostra que estava ele atento aos Códigos existentes, como o Chileno, o Português, o Austríaco, o da Luisiânia; assinalava os textos do Esboço de Freitas; examinava a doutrina (Marcadé, Aubry et Rau, Laurent, Zachariae, Caen, Coelho da Rocha); a Savigny referia-se duas vezes nessa pequena amostra de suas notas; e citava o Cours d'Institutes et d'Histoire du Droit Romain do belga P. Namur.

43. p. 289-311.

44. p. 455-504.

45. Projeto do código civil brasileiro do dr. Joaquim Felício dos Santos precedido dos atos oficiais relativos ao assunto e seguido de um aditamento contendo os apontamentos do código civil organizados pelo conselheiro José Thomaz Nabuco de Araújo, Rio de Janeiro, Nacional, 1882.

46. Um estadista do Império, Rio de Janeiro, Nova Aguilar, 1975, nota às p. 914-915. 
O último projeto de Código Civil elaborado no Império é o de Felício dos Santos, advogado que, em março de 1881, ofereceu ao Governo seus Apontamentos para o Projeto de Código Civil Brasileiro. Foi então nomeada uma comissão, para examiná-los, constituída por cinco dos mais notáveis civilistas da época: Lafayette Rodrigues Pereira, Antônio Joaquim Ribas, Antônio Ferreira Viana, Francisco Justino Gonçalves de Andrade e Antônio Coelho Rodrigues. Em setembro do mesmo ano, essa Comissão se manifestou no sentido de que, embora fossem os Apontamentos trabalho de elevado mérito, deveriam sofrer alterações para tornar-se um projeto em condições de ser revisto. Em vista disso, determinou o Governo que essa mesma Comissão (e nela teve ingresso Felício dos Santos) passasse a ter caráter permanente e organizasse o Projeto de Código Civil. Entretanto, pela retirada voluntária de alguns de seus membros, os trabalhos não chegaram a bom termo, e, em 1884 a 1887, Felício dos Santos publicou cinco volumes de comentários aos 2.692 artigos que o compunham. Antônio Coelho Rodrigues, que examinou mais aprofundadamente esse Projeto, o criticou largamente quanto ao plano adotado, à sua execução e à sua forma. ${ }^{47}$ O plano era inspirado no civilista português Coelho da Rocha: título preliminar (Da publicação e efeitos e aplicação das leis em geral), parte geral (constituída de 3 livros sobre, respectivamente, as pessoas, as coisas e os atos jurídicos em geral) e parte especial (com também 3 liṿros referentes às pessoas, às coisas e aos atos jurídicos em particular).

No ano mesmo em que se proclama a República - 1889 ,, o Visconde de Ouro Preto organizou um ministério cujo Ministro da Justiça foi Cândido de Oliveira, que, menos de um mês depois de haver sido nomeado, constituiu comissão para elaborar novo projeto de código civil. Dela, dentre outros, faziam parte Afonso Pena, Olegário Herculano de Aquino e Castro, Silva Costa e Coelho Rodrigues. Sob a presidência do próprio Imperador D. Pedro II, reuniu-se oito vezes, tendo sido dissolvida pelo advento do novo regime político. 48

47. Projeto do código civil precedido da história documentada do mesmo e dos anteriores, Rio de Janeiro, Tipografia do Jornal do Brasil, 1897, p. 227 e ss.

48. As atas dessas reuniões se encontram no folheto Projeto do código civil brasileiro em 1889 (editado no Porto, em 1906), e na Revista do Instituto Histórico e Geográfico Brasileiro, t. 68, parte I, p. 7-48. 
Proclamada a República, e ainda durante o governo provisório, Campos Sales, como Ministro da Justiça, contrata com Antônio Coelho Rodrigues, em 1890, a elaboração de Projeto de Código Civil. Redigido quase integralmente na Suíça - e fortemente inspirado no Código Civil de Zurich -, o trabalho de Coelho Rodrigues foi concluído em janeiro de 1893, e, logo após, entregue ao governo, que nomeou, para examiná-la, uma comissão de três juristas. Seu parecer foi contrário à acolhida do Projeto, tendo havido resposta de seu autor, réplica da Comissão e tréplica daquele. O plano do Projeto é este: Parte Geral (dividida em três livros: o primeiro relativo às pessoas; o segundo, aos bens; e o terceiro, aos fatos e atos jurídicos) e Parte Especial (constituída de quatro livros: o primeiro referente à obrigações; o segundo, à posse, à propriedade e aos outros direitos reais; o terceiro, ao direito de família; e o quarto, ao direito das sucessões). Esta síntese da personalidade de Coelho Rodrigues feita por Clóvis Bevilaqua, anos mais tarde, ao escrever a História da Faculdade de Direito do Recife, deflui, com exatidão, do conteúdo do seu Projeto: "... a figura de Coelho Rodrigues se nos apresenta como uma forte inteligência bem aparelhada por sólidos estudos, em que o espirito de rebeldia se associava, de modo bizarro, ao apego das tradiçōes, os surtos progressistas e a remora de certos preconceitos" 49 Aliás como salienta Pontes de Miranda ${ }^{50}$, Clóvis Bevilaqua tomou dele vários dispositivos para o Projeto que afinal viria a ser nosso Código Civil, e, por isso, muitas de suas inovações resultam do espírito progressista de Coelho Rodrigues, apesar de sua arraigada formação romanista. Em 1899, convidado por Epitácio Pessoa, então Ministro da Justiça, para elaborar Projeto de Código Civil aproveitando, no possível, os trabalhos anteriores -, Clóvis Bevilaqua inicia a obra no princípio de abril desse ano, e a conclui nos últimos dias de outubro. Ouvidos alguns jurisconsultos, resolveu o Governo nomear uma Comissão para rever o Projeto, e dela fizeram parte cinco eminentes juristas: Olegário Herculano de Aquino e Castro, Amphilóphio Botelho Freire de Carvalho, Joaquim da Costa Barradas, Francisco de Paula Lacerda de Almeida e João Evangelista Sayão Bulhões Carvalho. A essa comissão assim se referiria Rui

49. História da Faculdade de Direito do Recife, $2^{\text {a }}$ ed., p. 339-340.

50. Fontes e evolução do direito civil brasileiro, Rio de Janeiro, Pimenta de Mello \& C., 1928, p. 117,118 e 120 . 
Barbosa no parecer jurídico que, no Senado, começou a escrever em 1905, e que ficou inacabado:

"A Comissão Revisora constava, entretanto, no seu seio: o decano de nossa magistratura, que preside ao Supremo Tribunal Federal, um dos anciãos do nosso foro; o Cons $^{\mathrm{o}}$ Barradas, experimentado na administração pública sob o antigo regime, e, sob o atual, na magistratura suprema da União; Amphilóphio Botelho em cuja pessoa o grande tribunal republicano contribuía com mais um dos seus antigos e dos seus mais eminentes membros para aquela junta, profissional de rara cultura jurídica e consciência excepcionalmente austera: os Drs. Lacerda de Almeida e Bulhões de Carvalho, enfim, altas sumidades no direito civil brasileiro, consumados práticos $e$ temperamentos notavelmente ponderados" ${ }^{51}$

Nesse mesmo ano de 1899, e antes de se iniciarem as reuniões dessa comissão, Carlos Augusto de Carvalho, como contribuição informativa para o estudo do Projeto de Clóvis Bevilaqua, publicou uma consolidação das leis civis vigentes no Brasil, sob o título: Direito Civil Brasileiro Recopilado ou Nova Consolidação das Leis Civis, onde reuniu, sistematicamente, as leis civis vigentes no País em 11 de agosto de 1899.

Depois de duas revisões (a segunda com a participação de Clóvis Bevilaqua) realizadas pela comissão acima referida, o Projeto foi submetido, em novembro de 1900, ao Congresso Nacional, onde, após longa e nem sempre calma tramitação na Câmara dos Deputados e no Senado, foi ele aprovado em sessão da Câmara dos Deputados em 26 de dezembro de 1915, com a presença de 120 membros daquela Casa. Sancionado em $1^{o}$ de janeiro de 1916, entrou o Código Civil brasileiro em vigor em $1^{\mathrm{o}}$ de janeiro de 1917.

51. Código civil: parecer jurídico, in Obras completas de Rui Barbosa, 1905, v. 32, t. 3, p. 303, Rio de Janeiro, Ministério da Educação e Cultura, 1968. 


\section{3. o cóDIGo CIVIL.}

No prefácio que, em 1928, redigiu para a tradução francesa do Código Civil brasileiro feita por Goulé, Daguin e Tizac, observou Clóvis Bevilaqua, quanto às fontes dessa codificação:

"O Código Civil brasileiro se esforçou em fundir numa harmoniosa síntese as diversas correntes jurídicas que contribuíram para formá-lo. Em primeiro lugar, a tradição nacional, tendo por base o direito romano e o direito português, mas sempre orientado para um ideal de justiça e de liberdade e preocupaçāo em responder às necessidades da civilização moderna; depois, a influência do Código Civil francês e da doutrina francesa, que sempre gozaram de muito grande prestígio junto aos juristas sul-americanos; a influência dos Códigos português, espanhol, italiano, argentino e do Cantão de Zurich, enfim a das legislaçōes mais modernas, o Código Civil alemão e o Código suíço.

O Código Civil brasileiro, inspirando-se no direito estrangeiro estudado na legislação e na doutrina, reflete imagem fiel da época em que foi publicado; ele fixa um momento de evoluçāo jurídica mundial. Guarda, todavia, sua fisionomia original, tanto no aspecto técnico, quanto no social.

Tecnicamente, é ele a criação própria dos jurisconsultos brasileiros que, desde Teixeira de Freitas e todos os que, com ele ou depois dele, emprestaram sua colaboração ao preparo do Código, todos formados pela cultura brasileira e esforçando-se em satisfazer os interesses da comunidade em cujo seio viviam, servindo-se dos meios que ela mesma lhes oferecia.

Socialmente, o Código Civil é a expressão exata e característica da sociedade brasileira atual. Sem dúvida, os princípios sobre os quais ela se baseia: sentimento de 
igualdade, que coloca no mesmo nivel todos os indivíduos do grupo social quaisquer que sejam sua origem $e$ sua situação patrimonial, proteção $e$ consolidação da família, emancipação da mulher, sacerdotisa do lar, igualdade jurídica dos sexos, etc., são as conquistas ético-jurídicas da civilização geral. Mas, realizando esses princípios, o Código não procedeu por justaposição, incorporou-os ao organismo social, revestindo-os das modalidades apropriadas à sociedade brasileira, como a constituiram as condições de seu desenvolvimento histórico". 52

Esse resultado de influências se explica pela formação dos juristas que contribuíram para a feitura do Código Civil brasileiro e pelas circustâncias em que foi ele elaborado.

Pertencia Clóvis Bevilaqua ao movimento cultural que ficou conhecido como a Escola do Recife, o qual teve por corifeu Tobias Barreto, cuja tendência germanizante o caracterizou. Antes mesmo de redigir o Projeto de Código Civil, que é de 1899, suas obras demonstram sólido conhecimento da literatura jurídica alemã, inclusive a pandectista. Dentre os romanistas, citava, com freqüência, Mackeldey, Ihering, Savigny, Bonfante, Van Wetter, Cuq, Maynz, Leist, Padeletti, Cogliolo.

O germanismo e o romanismo de Clóvis se evidenciam em seu Projeto de Código Civil, com manifesta preponderância do último.

De sólida formação romanística eram os membros da Comissão do Governo que revisaram esse projeto. Sob esse aspecto, dois se destacavam: Bulhões de Carvalho e Lacerda de Almeida. Este último era, também, notável conhecedor da literatura jurídica germânica.

Nos debates que se travaram no Congresso Nacional sobre o projeto de Clóvis Bevilaqua, impressiona a desenvoltura de Coelho Rodrigues na invocação dos textos romanos, nas mais diversas questões de direito civil.

52. Code civil des Éstats-Unis du Brésil; traduit et annoté par P. Goulé, C. Daguin e G. D'Ardenne de Tizac, Paris, Nationale, 1928, n. 29, p. 48-49. 
Ressalta, aí, igualmente, o preparo romanístico de Clóvis Bevilaqua, de Amaro Cavalcanti, de Andrade Figueira. Este Andrade Figueira - se destacou como o defensor dos princípios tradicionais de nosso direito civil, impedindo, por vezes, a adoção de preceitos modernos que deveriam ter sido acolhidos.

A tradição jurídica brasileira se assentava, fundamentalmente, nos direitos romano, canônico e português, especialmente no primeiro. Em 1903, no Curso de Legislação Comparada, observava Cândido de Oliveira que "essencialmente romano é o alicerce da nossa legislação", e arrematava:

"Atualmente, (ainda se pode dizer com segurança) quase nenhuma das figuras do direito privado escapou à influência do romanismo.

Se a Ord. Liv. III, T. 64, prin. manda aplicar as Leis Imperiais, nos casos não previstos, não significa o preceito a repudiação da colação justinianéia quando o direito pátrio é completo.

Mesmo sem a lacuna do texto, que faz dela a lei suplementar, o conhecimento dos seus princípios seria o melhor guia no estudo do direito nacional" ${ }^{52 a}$

Não é de admirar, portanto, que, ao identificar as fontes materiais do Código Civil brasileiro, escrevesse Pontes de Miranda, em 1928:

"Das aproximadamente 1929 fontes do Código Civil, ao direito anterior pertencem 479, à doutrina já vigente antes do Código Civil, 272, e ao Esboço de Teixeira de Freitas, 189. Isto quer dizer: em tudo que se alterou, foi o Esboço a fonte principal.

Dos Códigos o que quantitativamente mais concorreu foi o Code Civil, 172, menos por si do que pela expressão moderna que dera a regras romanas. Em seguida, o português, 83, o italiano, 72, os Projetos alemães, 66, o Privatrechtliches Gesetzbuch für den

52a. Curso de legislação comparada - parte geral: as fontes, Rio de Janeiro, Jacinto Ribeiro dos Santos, 1903, p. 140. 
Kanton Zürich, 67, o espanhol, 32, a Lei suiça de 1881, 31, o Código Civil argentino, 17, o direito romano (diretamente) 19, o B.G.B. austríaco, 7, o Código Civil chileno, 7, o mexicano, 4, o uruguaio, 2, o peruano, 2, $e$ outros. As fontes alemãs foram as mais importantes $e$ por vezes os outros Códigos foram veículos das influências alemãs e austríacas. Mas, se as inovaçōes em relação ao direito anterior foram 1178, aos Códigos estrangeiros pediu-se menos de metade destas, pois foram de elaboração brasileira mais de 670. Concorreram para isto: Esboço de Teixeira de Freitas, 189, Projeto de Felício dos Santos, 49, de Coelho Rodrigues, 154, de Bevilaqua, 135, revisto, 78, da Câmara dos Deputados, 40, Senado Federal, 26, e outros, 2 ou $1 " .53$

Ao estabelecer que 19 foram as contribuições diretas do direito romano - e, nas páginas seguintes da mesma obra, alude aos arts. 43, III, 49, 50, 55, 57, 291 do Código Civil brasileiro -, não quis, obviamente, Pontes de Miranda reduzir a tanto (o que iria contra a própria evidência) a influência do direito romano em nossa codificação civil, mas, sim, caracterizar a circunstância de que ele se exerceu, geralmente, por intermédio da doutrina vigente no Brasil ou de Códigos e de Projetos fortemente impregnados de romanismo. Não há, portanto, contradição entre a assertiva de Pontes de Miranda e as de Abelardo Lobo ("Se passarmos em revista os 1807 artigos de nosso Código Civil, verificaremos que mais de quatro quintos deles, ou sejam 1445, são produtos de cultura romana..." $)^{54}$ e de Gaetano Sciascia ("É bem sabido que o Código Civil brasileiro assumiu e desenvolveu nas suas linhas gerais a obra da pandectística do século XLX. Quase a cada artigo da lei podem buscar-se os correspondentes textos romanos, os quais apresentam as relativas fatispécies na mais viva realidade e na infinita variedade

53. Ob. cit., n. 50, p. 119-120.

54. Curso de direito romano, Rio de Janeiro, 1931, v. 1, p. 51. 
dos acontecimentos humanos"54a; e "mas, assim como é certamente a lingua portuguesa a mais próxima da língua originária, também o direito civil brasileiro parece-nos mais chegado ao direito romano do que o direito civil italiano"). ${ }^{55} \mathrm{E}$ tanto assim é que o próprio Pontes de Miranda, na introdução que escreveu para a tradução alemã do Código Civil brasileiro dirigida por Heinsheimer, e publicada também em 1928, reproduz a estatística acima referida, com uma alteração digna de nota: ao aludir à contribuição do Código de Napoleão, mantém a observação de que ela decorreu mais da expressão moderna que deram às regras romanas, mas acrescenta imediatamente após (posição em que a afirmação que se segue não se encontrava nas Fontes e evolução do direito civil brasileiro) que, diretamente do direito romano, nos vieram 19 preceitos. ${ }^{56}$

Bem fundada, portanto, é esta apreciação que o Código Civil brasileiro mereceu de Hans Carl Nipperdey, nas edições por ele reelaboradas da notável Allgemeiner Teil des bürgerlichen Rechts do Lehrbuch des bürgerlichen Rechts de Enneccerus, Kipp e Wolff:

" $A$ mais independente das codificações latinoamericanas é o Código Civil brasileiro de 1.1.1916. Dos 1807 artigos que o integram cerca da metade deriva de códigos europeus, a saber do francês e do português, sendo que 62 artigos do Código Civil alemão. $A$ outra metade se funda em idéias de juristas brasileiros $e$ recolhe o direito consuetudinário. $A$ ordenação das matérias guarda ampla correlação com o Código Civil alemão, embora sua articulação numa parte geral $e$ numa parte especial seja diversa". 57

54a. Direito romano e direito civil brasileiro, Sāo Paulo, Saraiva, 1947, p. 205.

55. As relaçōes entre o Brasil e a Itália no campo do direito, in Varietà giuridiche: scritti brasiliani di diritto romano e moderno, Milano, Giuffrè, 1956, p. 374-375.

56. Die Zivilgesetze der Gegenwart Band III: Brasilien Codigo Civil, Berlin-Leipzig, J. Bensheimer-Mannheim, 1928, p. 40.

57. Lehrbuch des Bürgerlichen Rechts, Allgemeiner Teil des bürgerlichen Rechts, erster Band, erster halbband, Tübingen, J. C. B. Mohr (Paul Siebeck), 1952, § 29, X, p. 113. 
No tocante à sistematização, o Código Civil brasileiro orientou-se, nas linhas fundamentais, pela seguida pelo Código Civil alemão. Nessa linha, aliás, já se encontravam os trabalhos da Comissão que fora constituída em 1889 para elaborar um projeto de Código Civil e o Projeto de Coelho Rodrigues. Em alguns pontos, porém, o Código Civil brasileiro se afastou do sistema germânico: foi precedido de uma Introdução, com dispositivos referentes às normas jurídicas em geral e à sua aplicação no tempo e no espaço, dos quais a numeração é distinta da do Código; a ausência e disposições gerais sobre o contrato se deslocaram da parte geral para a parte especial; e a ordem da parte especial, ao invés de ser a do B.G.B. - direito das obrigações, direito das coisas, direito de familia e direito das sucessões -, é esta: direito de familia, direito das coisas, direito das obrigações e direito das sucessões. Nas Observaçōes para esclarecimento do Código Civil Brasileiro que servem de exposição de motivos de seu Projeto, Clóvis Bevilaqua justificou essa alteração na ordem da parte especial, com a colocação do direito de família em primeiro lugar, aduzindo, entre outros argumentos, estes dois:

"b) Adotado o critério classificador da generalização decrescente, depois da parte geral, na qual se incluem sob uma feiçāo abstrata, os princípios aplicáveis a todos os momentos, situação e formas do Direito privado, devemos enfrentar os institutos jurídicos do direito da família, que são partes integrantes dos fundamentos de toda a sociedade civil, interessam, como diz Menger, à base natural da sociedade e têm, portanto, maior generalidade do que as instituições jurídicas da propriedade;

c) Se o homem socialmente considerado tem primasia sobre o homem como individuo; se os interesses altruistas preferem aos egoísticos; se, como reconhece Savigny, os bens são uma extensão do poder do individuo, um atributo de sua personalidade, cabe a precedência, por amor da sociologia e da lógica, aos institutos da família, círculo de organizaçāo social, 
sobre os institutos econômicos, meios de assegurar a conservação e o desenvolvimento da vida social" ${ }^{58}$

A Introdução do Código Civil brasileiro que com ele entrou em vigor em $1^{\varrho}$ de janeiro de 1917 é constituída de 21 artigos. Já o Código Civil propriamente dito tem 1.807 artigos, cuja matéria está assim distribuída:

PARTE GERAL: Livro I - Das Pessoas.

Livro II - Dos Bens.

Livro III - Dos Fatos Jurídicos.

PARTE ESPECIAL: Livro I - Do Direito de Família.

Livro II - Do Direito das Coisas.

Livro III - Do Direito das Obrigações.

Livro IV - Do Direito das Sucessões.

Sobre sua técnica, bem a apreciou o grande historiador do direito português, Manuel Paulo Merêa, em obra Código Civil Brasileiro Anotado - que publicou em 1917:

"Na sua parte técnica, o código merece que se lhe não regateiem elogios pela forma por que se evitaram os dois grandes escolhos do legislador: o perigo do exagero doutrinário, das definições e divisões escolásticas, das abstrações nebulosas, $e$ o do exagerado detalhe de regulamentaçāo, da exposiçāo casuística das matérias, que é um entrave à tarefa do intérprete e do juiz. $O$ Código Civil Brasileiro aparece-nos como um código claro, sóbrio, prático, popular, comparável nesta parte ao código civil suiço, cuja técnica tem sido tão calorosamente aplaudida". 59

58. Projeto do código civil brasileiro: trabalhos da comissão especial da Câmara dos Deputados, Imprensa Nacional, 1902, v. 1, p. 15.

59. Código civil brasileiro, Lisboa, Clássica, 1917, p. XV. 
Quanto ao conteúdo do Código Civil brasileiro, algumas observações devem ser feitas.

O Livro I (Das Pessoas) da Parte Geral trata das pessoas naturais e das pessoas jurídicas. No art. $3^{\circ}$ dispõe que "a lei não distingue entre nacionais e estrangeiros quanto à aquisição e ao gozo dos direitos civis". O início da personalidade civil do homem ocorre com o nascimento com vida, pondo, porém, a lei a salvo, desde a concepção, os direitos do nascituro (art. $\left.4^{q}\right)$. Entre os relativamente incapazes de fato, encontram-se, ao lado dos maiores de $\mathbf{1 6}$ anos e menores de 21 anos, as mulheres casadas enquanto subsistir a sociedade conjugal, os pródigos e os silvícolas, ficando estes sujeitos a regime tutelar estabelecido em leis e regulamentos especiais, o qual cessará à medida de sua adaptação à civilização (art. $6^{0}$ ). A menoridade termina aos 21 anos completos (art. $9^{\mathbf{0}}$ ). No tocante à comoriência, adota a solução da presunção iuris tantum de que os comorientes se têm como simultaneamente mortos (art. 11). Distingue as pessoas jurídicas de direito público interno ou externo e as de direito privado (art. 13), estabelecendo, quanto à responsabilidade das pessoas jurídicas de direito público, que são elas "civilmente responsáveis por atos dos seus representantes que nessa qualidade causem danos a terceiros, procedendo de modo contrário ao direito ou faltando a dever prescrito por lei, salvo o direito regressivo contra os causadores do dano" (art. 15). Com relação às pessoas jurídicas de direito privado, disciplinam-se as sociedades ou associações civis (arts. 20 a 23) e as fundações (arts. 24 a 30). O domicílio civil da pessoa natural é tanto a sua residência com intenção de permanência quanto o centro de suas ocupações habituais (arts. 31 e 32). Admite-se a pluralidade de domicilio da pessoa natural (art. 32), e se tem por domicilio de quem não tenha residência habitual, ou empregue a vida em viagens, sem ponto central de negócios, o lugar onde for encontrada (art. 33).

No Livro II (Dos Bens) da Parte Geral, traçam-se as normas das diferentes classes de bens, dispondo sobre os móveis e imóveis, os fungiveis, os consumíveis, os divisíveis, os singulares (simples e compostos), os coletivos, que são as universitates facti e as universitates iuris, os principais e os acessórios, os públicos e os particulares, e os que estão fora do comércio (arts. 43 a 69). Ainda nesse livro é disciplinado o bem de família, que corresponde ao homestead, com 
dispositivo que protege os credores, afastando-se, assim, a crítica comumente feita e esse instituto (arts. 70 a 73).

O Livro III (Dos Fatos Jurídicos) da Parte Geral se ocupa fundamentalmente dos atos jurídicos (arts. 81 a 158), expressão genérica que, na técnica do Código Civil, traduz o que hoje preferencialmente se denomina negócio jurídico. $\mathrm{O}$ ato jurídico é definido segundo a sua concepção subjetiva, dominante na época. Como defeitos dos atos jurídicos se disciplinam o erro ou ignorância, o dolo, a coação, a simulação e a fraude contra credores. A condição, o termo e o modo ou encargos são regulados como "modalidades dos atos jurídicos" A invalidade dos atos jurídicos é disciplinada nas suas duas graduações: a nulidade e a anulabilidade. Ainda nesse Livro se encontram os preceitos (arts. 159 e 160) sobre os atos ilícitos absolutos (os que violam direitos oponíveis erga omnes) e sobre a prescrição (sem distinguí-la, contudo, da decadência, o que foi feito, posteriormente, pela doutrina) (arts. 171 a 179).

O direito de família é objeto do Livro I da Parte Especial do Código. Está ele dividido em 6 títulos. No título I encontram-se os preceitos relativos ao casamento (formalidades preliminares, impedimentos, oposição de impedimentos, celebração do casamento, provas do casamento, casamento nulo e anulável e disposições penais), arts. 180 a 228. O Código Civil só conhece o casamento civil. Nos impedimentos ao matrimônio nele enumerados, distinguem-se os impedimentos dirimentes absolutos, os impedimentos dirimentes relativos e os impedimentos impedientes, conforme, respectivamente, acarretem a nulidade, a anulabilidade ou a imposição de sanções (que estão estabelecidas nas disposições penais desse título), se não forem observados. No título II (arts. 229 a 255) se disciplinam os efeios jurídicos do casamento; nele se estabelece a irrevogabilidade do regime dos bens entre os cônjuges, seus deveres recíprocos e os direitos e deveres de cada um deles; a chefia da sociedade conjugal é outorgada ao marido, que, no entanto, não pode, com relação aos bens, qualquer que seja o regime deles, praticar vários atos (como, por exemplo, alienar, hipotecar ou gravar de ônus real os imóveis) sem a autorização da mulher (outorga uxória), salvo se houver suprimento judicial; em maior número, porém, são os atos que a mulher não pode realizar sem a autorização do marido (inclusive o de exercer profissão), que, no entanto, em certos casos, pode ser suprida judicialmente. No título III, encontram-se as normas sobre os regimes de 
bens entre os cônjuges (arts. 256 a 314); aí se disciplinam os quatro regimes típicos: o da comunhão universal de bens (que é o legal), o da comunhão parcial, o da separação e o dotal. No título IV, cuida-se da dissolução da sociedade conjugal e da proteção da pessoa dos filhos (arts. 315 a 329); aí se verifica que não se admite o divórcio, mas apenas o desquite amigável ou judicial que não extingue o vínculo conjugal (por isso o cônjuge desquitado não pode contrair novo casamento), mas apenas a sociedade conjugal. Das relações de parentesco trata o título V (arts. 330 a 405), que disciplina a filiação legítima, a legitimação, o reconhecimento dos filhos ilegítimos, a adoção, o pátrio poder e os alimentos. Por fim, os instrumentos da tutela, da curatela e da ausência são regulados no título VI (arts. 406 a 484).

O Livro II da Parte Especial diz respeito ao direito das coisas. Divide-se em três títulos: o relativo à posse (título I, arts. 485 a 523); o referente à propriedade (arts. 524 a 673); e o concernente aos direitos reais sobre coisas alheias (arts. 674 a 862). Quanto à posse, é ela caracterizada como o exercício de fato, pleno ou não, de alguns dos poderes inerentes à propriedade; organiza-se horizontalmente em posse de coisa e posse de direito, e verticalmente em posse direta e posse indireta; detentor é aquele que, achando-se em relação de dependência para com outro, conserva a posse em nome deste e em cumprimento de ordens ou instruções suas. Os direitos reais são enumerados taxativamente (numerus clausus) e se dividem em dois grandes grupos: o de propriedade de que se ocupa o Título II, distinguindo a propriedade imóvel da propriedade móvel, e tratando, também, do condomínio e da denominada propriedade literária, científica e artística; e os direitos reais sobre coisas alheias, que são: a enfiteuse, as servidões, o usufruto, o uso, a habitação, as rendas expressamente constituídas sobre imóveis, o penhor, a anticrese e a hipoteca.

O direito das obrigações é disciplinado no Livro III da Parte Especial, o qual se divide em nove títulos, a saber: "Das modalidades das obrigações" (arts. 863 a 927), "Dos efeitos das obrigações" (arts. 928 a 1.064), "Da cessão de crédito" (arts. 1.065 a 1.078), "Dos contratos" (arts. 1.079 a 1.121), "Das várias espécies de contratos" (arts. 1.122 a 1.504), "Das obrigações por declaração unilateral da vontade" (arts. 1.505 a 1.517), "Das obrigações por atos ilícitos" (arts. 1.518 a 1.532), "Da liquidação das obrigações" (arts. 1.533 a 1.553) e do "Do concurso de credores" (arts. 1.554 a 1.571). Nota-se, nesse livro, a omissão de 
disciplina da cessão de débito. Os contratos típicos nele regulados são: a compra e venda, a troca, a doação, a locação (de coisa, de serviços e a empreitada), o empréstimo (comodato e mútuo), o depósito (voluntário e necessário), o mandato, a edição, a representação dramática, a sociedade, a parceria rural (agrícola e pecuária), a constituição de renda, o seguro e a fiança. Dos títulos ao portador e da promessa de recompensa decorrem as obrigações por declaração unilateral de vontade.

Finalmente, o Livro IV da Parte Geral tem por objeto o direito das sucessões. Dividido em quatro títulos ("Da sucessão em geral", arts. 1.572 a 1.602; "Da sucessão legítima", arts. 1.603 a 1.625; "Da sucessão testamentária", arts. 1.626 a 1.769; e "Do inventário e partilha", arts. 1.770 a 1.805), acolhe ele o instituto da saisine, ao estabelecer, no art. 1.572, que, "aberta a sucessão, $o$ domínio e a posse da herança transmitem-se, desde logo, aos herdeiros legitimos $e$ testamentários"; a sucessão legítima se defere nesta ordem: descendentes, ascendentes, cônjuge sobrevivente, colaterais (até o sexto grau; atualmente, até o $4^{\circ}$ grau, por força do Decreto-lei n. 9.461, de 15 de julho de 1946) Estadosmembros, Distrito Federal ou União (conforme o domicílio do de cuius); três são as formas ordinárias de testamento (o público, o cerrado e o particular) e como testamentos especiais se regulam o testamento marítimo e o testamento militar; admite-se o codicilo.

\section{ALTERAÇÕES E INOVAÇÕES INTRODUZIDAS PELA LEGISLAÇÃO POSTERIOR AO CÓDIGO CIVIL.}

Com a entrada em vigor do Código Civil em $1^{\circ}$ de janeiro de 1917, verificou-se, desde logo, que vários de seus dispositivos tinham sido publicados com incorreções ou apresentavam defeitos de forma capazes de dificultar a sua interpretação. A Lei n. 3.725, de 15 de janeiro de 1919, emendando 192 artigos do Código Civil, na maior parte apenas quanto à redação, procurou sanar esses defeitos.

A partir de então até os dias que correm, modificações mais profundas se fizeram no direito civil brasileiro.

Eis as principais.

Ao contrário do Código Civil que não estabelecia limitação na estipulação de juros nos contratos, o Decreto n. 22.626, de 7 de abril de 1933, a 
veda acima do dobro da taxa legal (esta de $6 \%$ a.a.), e determina a nulidade dos contratos usurários. Posteriormente, a Lei n. 1.521, de 26 de dezembro de 1951, além de considerar crimes contra a economia popular a usura pecuniária e a usura real, estabelece, em seu art. $4^{\circ}, \S 3^{\circ}$, que "a estipulação de juros ou lucros usurários será nula, devendo o juiz ajustá-los à medida legal, ou, caso já tenha sido cumprida, ordenar a restituição da quantia paga em excesso, com os juros legais a contar da data do pagamento indevido"

Em se tratando de locação para fins residenciais e não-residenciais, a disciplina desses contratos experimentou profundas modificações decorrentes dos interesses sociais em conflito. Já o Decreto n. 24.150, de 20 de abril de 1934, disciplinou a locação de prédios destinados a fins comerciais e industriais, e continua em vigor com algumas alterações introduzidas pela Lei n. 6.014, de 27 de dezembro de 1973. No tocante à locação de prédios residenciais, o desequilibrio entre a oferta e a procura de imóveis com a alta dos aluguéis acarretou, ainda na década de 30 (Lei n. 4.403, de 22 de dezembro de 1928), legislação de inquilinato temporária; a partir, porém, de 1942 (e a série de leis que, a respeito, se elaboraram se inicia com o Decreto-lei n. 4.598, de 20 de agosto de 1942, e, entre as que se lhe seguiram, destacaram-se a Lei n. 1.300, de 22 de dezembro de 1950, e a Lei n. 4.864, de 29 de novembro de 1965, que excluiu da incidência da legislação do inquilinato as locações não-residenciais, subordinando-as, conforme seus fins, ao regime do Código Civil ou do citado Decreto n. 24.150/34), essa legislação tomou o caráter de permanente. Atualmente, a Lei n. 6.649, de 16 de maio de 1979, com as alterações da Lei n. 6.698 , de 15 de outubro de 1979, regula a locação dos prédios urbanos, exceto as locações para fins comerciais ou industriais que continuam regidas pelo Decreto n. 24.150/34 (salvo se não proposta a ação renovatória desses contratos) e as dos prédios urbanos de propriedade da União.

A venda a crédito com reserva de domínio só depois de utilizada na prática é que foi reconhecida pela legislação brasileira, o que ocorreu, pela primeira vez, com o Decreto-lei n. 869, de 18 de novembro de 1938. Sua disciplina, hoje, se faz, substancialmente, pelos arts. 1.070 e 1.071 do Código de Processo Civil (Lei n. 5.869, de 11 de janeiro de 1973).

O Código Civil permitia a estipulação do pagamento em certa espécie de moeda ou em moeda estrangeira. A legislação posterior (o Decreto $\mathbf{n}$. 
23.501, de 27 de novembro de 1933, atualmente revogado pelo Decreto-lei n. 857, de 11 de setembro de 1969, que disciplina essa matéria) a proibiu, exceto em se tratando de contratos internacionais.

A disciplina dos contratos de edição e de representação dramática feita pelo Código Civil (arts. 1.346 a 1.358 e 1.359 a 1.362, respectivamente) foi revogada pela Lei n. 5.988, de 14 de dezembro de 1973, que regula os direitos autorais, neles se compreendendo os direitos de autor e os direitos que the são conexos.

O direito real de aquisição do promitente comprador foi criado quanto aos imóveis não loteados pela Lei n. 649, de 11 de março de 1949, cujo art. $1^{\mathrm{o}}$ assim dispôs: "Os contratos, sem cláusula de arrependimento, de compromisso de compra-e-venda de imóveis não loteados, cujo preço tenha sido pago no ato de sua constituição ou deva sê-lo em uma ou mais prestações, desde que inscritos em qualquer tempo, atribuem aos compromissários direito real, oponivel a terceiros, e lhes confere o direito de adjudicação compulsória". Já anteriormente, quanto aos imóveis loteados, o Decreto-lei n. 58, de 10 de dezembro de 1937, no seu art. $5^{\circ}$, declarava que a averbação, no registro imobiliário, da promessa de compra-e-venda "atribui ao compromissário direito real oponivel a terceiro, quanto à alienação ou oneração posterior e far-se-á à vista do instrumento de compromisso de venda, em que o oficial lançará a nota indicativa do livro, página e data do assentamento". Direito real semelhante foi também foi conferido ao promitente cessionário pelo art. 69 da Lei n. 4.380 , de 21 de agosto de 1964, nestes termos: "O contrato de promessa de cessão de direitos relativos a imóveis não loteados, sem cláusula de arrependimento e com imissão de posse, uma vez inscrita no registro geral de imóveis, atribui ao promitente cessionário direito real oponivel a terceiro e confere direito à obtençāo compulsória da escritura definitiva de cessão, aplicando-se, neste caso, no que couber, o disposto no art. 16 do Decreto-lei n. 58, de 10 de dezembro de 1937, e no art. 346 do Código de Processo Civil".

Leis posteriores ao Código Civil atualizaram as normas dele sobre o penhor rural, bem como criaram outras espécies de penhor, sem desapossamento, relacionadas com atividades industriais (assim, por exemplo, o Decreto-lei n. 1.271, de 16 de maio de 1939, sobre penhor de máquinas e aparelhos utilizados na indústria; o Decreto-lei n. 1.697, de 23 de outubro de 
1939, que estendeu o penhor industrial aos produtos da suinocultura; e o Decreto-lei n. 3.168, de 2 de abril de 1941, sobre o penhor de sal e de coisas destinadas à exploração de salinas).

O condomínio por planos horizontais foi ignorado pelo Código Civil: Foi disciplinado, a princípio, pelo Decreto n. 5.481, de 25 de junho de 1928, alterado pelo Decreto-lei n. 5.234 e pela Lei n. 285, de 1943 e de 1948, respectivamente. Atualmente, é a Lei n. 4.591, de 16 de dezembro de 1964, que disciplina o condomínio em edificações e as incorporações imobiliárias.

$O$ instituto da alienação fiduciária em garantia foi criado, no sistema jurídico brasileiro, para atender à aspiração de novas garantias reais mais eficazes para a proteção do crédito do que as existentes. Trata-se de negócio jurídico bilateral que é análogo aos que visam à constituição dos direitos reais de garantia. A garantia real (a propriedade fiduciária) a cuja constituição visa a alienação fiduciária em garantia (contrato de direito das coisas) não nasce da simples celebração desta, mas, sim, do seu registro no Registro de Títulos e Documentos. Essa propriedade fiduciária, que é a garantia real, é uma modalidade de propriedade limitada cujas restrições - inclusive a resolubilidade lhe são impostas pela lei para atender ao seu escopo de garantia. Introduzida pelo art. 66 da Lei n. 4.728, de 14 de julho de 1965, relativa ao mercado de capitais, é atualmente disciplinada pelo Decreto-lei n. 911, de $1^{\circ}$ de outubro de 1969.

A interdição do toxicômano quer a limitada quer a plena, equiparadas, respectivamente, às incapacidades de fato relativa e absoluta - não é regulada no Código Civil, mas, sim, em diploma legal posterior a ele: o Decretolei n. 891, de 25 de novembro de 1938.

É de 10 de agosto de 1968 a Lei n. 5.479, que dispõe sobre a retirada e transplante de tecidos, órgãos e partes de cadáver para finalidade terapêutica e científica.

Mas é no direito de familia que se situam as maiores modificações sofridas pelo Código Civil. Vários de seus dispositivos nessa parte foram profundamente alterados, principalmente para melhorar a situação jurídica da mulher casada e a dos filhos ilegítimos. Nesse terreno, já a Lei n. 3.200, de 19 de abril de 1941, que dispunha sobre a organização e a proteção à familia, permitiu o casamento de colaterais do terceiro grau, desde que, submetidos a exame 
médico, se concluísse não haver inconveniente, na realização do casamento, quanto à saúde deles e da prole. Ademais, disciplinou ela o casamento religioso com efeitos civis, parte em que foi revogada pelas disposições, a propósito, da Lei n. 1.110, de 23 de maio de 1950; e, além disso, complementou as disposições do Código Civil sobre o bem de familia. Posteriormente, a Lei n. 883, de 21 de outubro de 1949, dispôs sobre o reconhecimento de filhos ilegítimos, permitindo a qualquer dos cônjuges, depois de dissolvida a sociedade conjugal, o reconhecimento de filho havido fora do matrimônio, e, ao filho, a ação para que se lhe declare a filiação. A Lei n. 3.133, de 8 de maio de 1957, introduziu várias alterações nos artigos do Código Civil concernentes à adoção. Nesse terreno, aliás, em 2 de junho de 1965, a Lei n. 4.655 acolhia, no Brasil, a legitimação adotiva, inspirada nos modelos francês e uruguaio. Atualmente, o Código de Menores (Lei n. 6.697, de 10 de outubro de 1979) dispõe, entre as providências de assistência e proteção do menor, a colocação deste em lar substituto, o que poderá ser feito por meio da adoção simples (que é a disciplinada pelo Código Civil) ou da adoção plena (que corresponde à legitimação adotiva). Profundas alterações na situação jurídica da mulher casada foram introduzidas nas modificações que a Lei n. 4.121, de 27 de agosto de 1962 (o denominado Estatuto da Mulher Casada) fez em vários dispositivos do Código Civil, acabando com a incapacidade relativa da esposa, dando-lhe a colaboração com o marido na chefia, por parte deste, da sociedade conjugal; melhorando sua posição com relação aos seus direitos e deveres, bem como quanto ao pátrio poder; e outorgando ao cônjuge sobrevivente, se o regime de bens do casamento não era o da comunhão universal, direito, enquanto durar a viuvez, ao usufruto de parte dos bens do cônjuge falecido, e, se o regime de bens do casamento era o da comunhão universal, o direito real de habitação relativamente ao imóvel destinado à residência da família, desde que o único bem daquela natureza a inventariar. E a Lei n. 6.515, de 26 de dezembro de 1977, que disciplinou a separação dos cônjuges e o divórcio, também fez alterações de monta quanto à proteção dos filhos, ao uso do nome de casada e aos alimentos, no caso de separação ou de divórcio.

Por fim, com a promulgação da atual Constituição Federal, em 5 de outubro de 1988, e tendo em vista o entendimento dominante de que até as normas constitucionais programáticas têm a eficácia de revogarem a legislação 
anterior com elas incompatíveis, sensíveis alterações - cuja exata determinação ainda não foi feita, em profundidade, pela doutrina e pela jurisprudência - se produzirem no terreno do direito de família. Assim, reconheceu-se, para o efeito de proteção do Estado, a união estável entre o homem e a mulher como entidade familiar, devendo a lei facilitar sua conversão em casamento (art. 226, § $3^{\circ}$ ); dispôs-se que os direitos e os deveres referentes à sociedade conjugal são exercidos igualmente pelo homem e pela mulher (art. 226, §5o); facilitou-se o divórcio, estabelecendo-se que "o casamento civil pode ser dissolvido pelo divórcio, após prévia separação judicial por mais de um ano nos casos expressos em lei, ou comprovada separação de fato por mais de dois anos" (art. 226, § 6º); determinou-se, quanto à adoção, que ela "será assistida pelo Poder Público, na forma da lei, que estabelecerá casos e condições de sua efetivação por parte de estrangeiros" (art. 227, § 5); equipararam-se os filhos, havidos ou não da relação de casamento, ou por adoção, estabelecendo-se que "terão os mesmos direitos $e$ qualificações, proibidas quaisquer designações discriminatórias relativas à filiação" (art. 227, § $6^{\circ}$ ). Por outro lado, pondo fim à controvérsia sobre a admissibilidade, ou não, em nosso sistema jurídico, do dano moral, assegurou-se, entre os direitos individuais, a indenização por ele (art. 5o, V e X). Criou-se, ainda, uma espécie de usucapião-moradia, ao preceituar-se no art. 183, que "aquele que possuir como sua área urbana de até duzentos e cinqüenta metros quadrados, por cinco anos, ininterruptamente e sem oposição, utilizando-a para sua moradia ou de sua família, adquirir-lhe-á o domínio, desde que não seja proprietário de outro imóvel urbano ou rural" (art. 183, caput); e, no art. 191, admitiu-se, em zona rural, o usucapião-trabalho: "aquele que, não sendo proprietário de imóvel rural ou urbano, possua como seu, por cinco anos ininterruptos, sem oposição, área de terra, em zona nural, não superior a cinqüenta hectares, tornando-a produtiva por seu trabalho ou de sua família, tendo nela sua moradia, adquirir-lhe-á a propriedade". Ademais, no art. 49 do Ato das Disposições Constitucionais Transitórias, permitiu-se que a lei extinga a enfiteuse em imóveis urbanos, estabelecendo princípios para a remição dos aforamentos mediante aquisição do domínio direto. 


\title{
5. OS MOVIMENTOS DE REFORMA DO CÓDIGO CIVIL.
}

De 1916 aos nossos dias, o Código Civil brasileiro já foi objeto, por três vezes, de tentativa de reforma. E, atualmente, está em curso uma quarta.

Delas, apenas a primeira ocorrida na década de 30 - não enfrentou o problema da unificação do direito privado. Embora o objetivo do Governo, naquela época, fosse a elaboração de novo Código Civil, os trabalhos que então se fizeram se limitaram a apresentar sugestões para a modificação do Código vigente, sendo que, posteriormente, um dos juristas nomeados para a elaboração dessa obra Eduardo Espínola chegou a salientar que seria preferivel rever o Código a substituí-lo, pois, assim se poderia, "deixando em vigor um corpo de lei, que honra a cultura jurídica brasileira: $1^{\circ}$ ) integrar o Código com a legislação posterior, que o tem aditado, modificado, derrogado; $2^{\circ}$ ) eliminar, no texto do Código, certas falhas oriundas da dubiedade de sentido de alguns artigos - cuja forma elegante trai o sentido real - e algumas contradições; $3^{\circ}$ ) alterar a substância de alguns institutos, que, como estâo, não correspondem às nossas necessidades sociais do momento" ${ }^{60}$

Em 1940, Orosimbo Nonato, Philadelpho Azevedo e Hahnemann Guimarães receberam do Governo Federal a incumbência de proceder à revisão do Código Civil, visando a

\begin{abstract}
"atender às modificações operadas por leis posteriores, seguir as modernas tendências do direito, mitigar os excessos do individualismo, incompativeis com a ordem jurídica dos tempos que correm, e reduzir a dualidade de princípios aplicáveis aos negócios civís e mercantis, em prol da unificação de preceitos, que devam reger todas as relações de ordem privada". 61
\end{abstract}

Em face disso, a Comissão entendeu que seria mais urgente a execução de trabalho no tocante ao direito das obrigações, até porque - como se

60. Tratado de direito civil brasileiro por Eduardo Espíndola e Eduardo Espíndola Filho, Rio de Janeiro, Freitas Bastos, 1939, v. 2, p. 554.

61. Anteprojeto de código das obrigaçōes: parte geral, Rio de Janeiro, Imprensa Nacional 1941, p. 5. 
lê na exposição de motivos que ela, em 24 de janeiro de 1941, apresentou ao então Ministro da Justiça, Francisco Campos - "a unificação dos princípios gerais sobre as obrigações e a disciplina dos contratos em espécie apresenta, ainda, a vantagem de resolver o problema da reforma do direito mercantil, que ficará, assim, reduzido a um restrito núcleo de preceitos reguladores da atividade profissional dos comerciantes; a matéria relativa às sociedades e ao transporte comportará, ainda, codificações autônomas". ${ }^{2}$ Com o Código de Obrigações (cujo anteprojeto da parte geral foi publicado pela Imprensa Nacional, tendo vindo à luz, posteriormente, na Revista $O$ Direito, parte do anteprojeto da parte especial) ${ }^{63}$ que a Comissão se propunha a elaborar, realizar-se-ia a unificação parcial do direito privado brasileiro. Embora essa tentativa não haja chegado a bom termo, teve o mérito de fazer reviver, mais intensamente, o problema da conveniência da unificação do direito privado.

Pelo Decreto n. 51.005, de 25 de julho de 1961, foi criada, no Ministério da Justiça, a Comissão de Estudos Legislativos, com a missão de dirigir e coordenar os trabalhos de reforma dos códigos brasileiros. $O$ então Ministro da Justiça, a quem, naquela época, incumbia, diretamente, a direção e a coordenação dos trabalhos nesse sentido, contratou vários juristas para a elaboração de anteprojetos para a reforma integral da codificação. No terreno do direito privado, foi estabelecida a diretriz da unificação do direito privado, nos moldes da Suíça, com a elaboração de um código civil e de um código das obrigações. Neste, far-se-ia a unificação do direito privado. A feitura do anteprojeto de código das obrigações coube a três juristas: Caio Mário da Silva Pereira (parte geral e contratos), Sylvio Marcondes (sociedades e exercício da atividade mercantil) e Theóphilo de Azeredo Santos (títulos de crédito). Ao Prof. Orlando Gomes se deu a incumbência da elaboração do anteprojeto de Código Civil.

Apresentados os três anteprojetos relativos ao Código das Obrigações, foram eles, depois de examinados por uma comissão revisora, transformados no Projeto de Código de Obrigações, dividido em três partes:

62. Ob. cit., p. 6.

63. Nos volumes 40 (às p. 44 e ss., a parte relativa a títulos de crédito) e 43 (às p. 34 e ss., alguns dos contratos em espécie). 
a) - a primeira, referente à "obrigação e suas fontes", correspondia ao anteprojeto de Caio Mário da Silva Pereira;

b) a segunda, relativa aos "títulos de crédito", resultava do anteprojeto de Theóphilo de Azeredo Santos; e

c) a terceira, concernente a "empresários e sociedades", derivava do anteprojeto de Sylvio Marcondes sobre sociedades e exercício da atividade mercantil.

Também o anteprojeto de Código Civil foi revisto por uma Comissão composta por seu autor, pelo Ministro Orosimbo Nonato e pelo Prof. Caio Mário da Silva Pereira.

Na Memória Justificativa do Anteprojeto de Reforma do Código Civil, publicada em 1963, Orlando Gomes, referindo-se às finalidades dessa reforma, esclarecia:

"Redigido no pensamento de atualizar, com espírito de. sistema, a legislação civil, o Anteprojeto coordena e consolida alterações introduzidas no Código por leis esparsas, e inova em inúmeros pontos.

Sem esse propósito de inovar não se justificaria a reforma do Código Civil". 64

E, em seguida, salientava:

"Inovar não significa, porém, amor indiscriminado à novidade, senão aproveitamento da experiência de outros povos e da própria experiência nacional condensadas na doutrina e na jurisprudência" 65

Daí, ter lançado mão o autor do Anteprojeto dos subsídios oferecidos, principalmente, pelos Códigos Civis da Suíça, da Itália, da Grécia, do México e do Peru, bem como do anteprojeto de reforma do Código Civil francês.

64. Memória justificativa do anteprojeto de reforma de código civil, Imprensa Nacional, 1963, p. 19.

65. Ibidem. 
As principais inovações que o projeto de Código Civil, em que se converteu esse Anteprojeto, procurou introduzir em nosso direito (deixadas de lado, portanto, aquelas que leis posteriores ao Código já haviam incorporado ao nosso sistema jurídico, como, por exemplo, o instituto da legitimação adotiva) eram, em linhas gerais, as seguintes:

\section{A) - quanto à distribuição da matéria:}

- retirava-se do Código Civil o livro relativo às Obrigações, tendo em vista a elaboração do Projeto de Código das Obrigações (à semelhança do que existe no direito suíço e no direito polonês), onde se fazia a unificação parcial do direito civil com o direito comercial; e

- ao contrário do Código Civil, não tinha o Projeto a Parte Geral, sendo o conteúdo desta distribuído pelos diversos livros deste, e, no concernente ao negócio jurídico, colocado na parte primeira do Projeto de Código das Obrigações;

B) quanto aos diferentes institutos jurídicos:

1) - no tocante às pessoas:

a maioridade passava a ocorrer aos dezoitos anos, cessando a incapacidade absoluta aos quatorze; e aos dezesseis podia ser concedida ao menor a emancipação voluntária;

- o ato de emancipação poderia ser cassado pelo juiz, quando o menor emancipado demonstrasse incapacidade de administrar os bens;

disciplinavam-se os direitos da personalidade;

- modificavam-se os conceitos de domicilio e de residência; e

- três anos depois do trânsito em julgado da sentença que declarava a morte presumida, podia seu cônjuge contrair novo casamento (se o que fosse declarado morto reaparecesse, o segundo matrimônio seria considerado nulo, mas produziria os efeitos do casamento putativo);

2) - relativamente ao direito de família:

- a idade mínima para contrair casamento passava a ser de 16 anos para o homem, e 14 para a mulher;

suprimiam-se alguns dos impedimentos matrimoniais consignados no Código Civil; 
distinguia-se a capacidade matrimonial dos impedimentos matrimoniais;

alterava-se o conceito de erro essencial quanto à pessoa de um dos cônjuges, como fundamento de anulação do casamento;

- se o regime de bens fosse o da separação absoluta, dispensava-se a outorga de um dos cônjuges para que o outro pudesse alienar ou gravar de ônus real seus bens imóveis, ou seus direitos reais sobre imóveis alheios; ou pleitear, como autor ou réu, acerca desses bens e direitos;

- a posição dos cônjuges, nas relações entre si ou com os filhos, passava a ser, em geral, de absoluta paridade;

- o regime da separação de bens com a comunhão de aquestos se tornava o regime legal de bens;

era abolido o regime dotal, o mesmo ocorrendo com o da comunhão parcial como disciplinado no Código Civil;

admitia-se, durante a constância da sociedade conjugal, a retratabilidade do regime de bens; $\mathrm{e}$

o filho nascido na constância do casamẹnto, qualquer que fosse a época de sua concepção, era legítimo;

3) - no concernente ao direito das coisas:

acentuava-se a função social do direito de propriedade, prescrevendo-se no art. 375 que "a propriedade não pode ser exercida em desacordo com seu fim econômico e social", e no art. 377 que "a propriedade, principalmente quando exercida sob a forma de empresa, deve conformar-se às exigências do bem comum, sujeitando-se às disposições legais que limitam seus conteúdos, impōem obrigaçōes e lhe reprimem os abusos";

disciplinava-se a passagem de cabos elétricos e de canos de gás em terreno alheio;

quanto aos direitos reais limitados, além de se abolirem o uso, a habitação e a anticrese, adotavam-se normas para estimular a extinção da enfiteuse; $\mathrm{e}$ 
4) no que dizia respeito ao direito das sucessões:

- eram chamados à sucessão legal os colaterais apenas até o terceiro grau;

o cônjuge passava a incluir-se entre os herdeiros necessários, tendo direito, a título de legítima, à metade dos bens do outro, se não houvesse descendentes ou ascendentes; e à quarta parte desses bens, se concorresse à sucessão com os filhos do outro cônjuge ou com os ascendentes deste, desde que o casamento não tivesse sido celebrado no regime da comunhão universal de bens;

- a legítima não comportava cláusula de inalienabilidade;

reconhecia-se direito sucessório à companheira do homem solteiro, desquitado ou viúvo; e

restringia-se a substituição fideicomissária, que era admitida apenas em favor dos descendentes do testador ainda não nascidos ao tempo de sua morte.

Uma vez mais, porém, não chegou a bom termo a tentativa de reforma do Código Civil. As inúmeras críticas que se levantaram, no país, contra certas inovações do Projeto de Código Civil, especialmente no terreno do direito de familia, fizeram que o Governo Federal, depois de ter enviado, em 12 de outubro de 1965, ambos os projetos (de Código Civil e de Código de Obrigações) ao Poder Legislativo voltasse atrás e os retirasse do Congresso, para seu mais acurado exame.

Em maio de 1969, por ato do Ministro da Justiça, naquela época o Prof. Luiz Antônio da Gama e Silva, foi designada Comissão para elaborar novo anteprojeto de Código Civil, a qual, sob a supervisão do Prof. Miguel Reale, foi constituída pelos seguintes Professores:

- José Carlos Moreira Alves (parte geral);

Clóvis Couto e Silva (direito de família);

- Agostinho de Arruda Alvim (direito das obrigações);

- Ebert Vianna Chamoun (direito das coisas);

- Torquato Castro (direito das sucessões); e

- Sylvio Marcondes (direito das sociedades).

Coube a essa comissão tarefa diversa daquela de que tinham sido incumbidos os professores Orlando Gomes, Caio Mário da Silva Pereira, Sylvio 
Marcondes e Theóphilo de Azeredo Santos. Com efeito, na reforma que se projetara em 1961, visava o Governo à reformulação total do direito privado, por meio da elaboração de dois Códigos que abrangessem o direito civil e o direito comercial. Outro foi o pensamento do Governo em 1969: a nova Comissão deveria elaborar anteprojeto em que se preservasse tudo aquilo que, no Código Civil vigente, continuasse compatível com a evolução social brasileira, modificando-o, apenas, no que com esta ou com o aprimoramento da ciência jurídica estivesse descompassado. Num ponto, porém, a orientação permaneceu inalterada: o novo Código Civil deveria proceder à unificação do direito privado. Por isso, a portaria ministerial atribuiu ao prof. Sylvio Marcondes a elaboração da parte concernente ao "direito das sociedades".

Em 1971, essa Comissão entregou ao então Ministro da Justiça, Prof. Alfredo Buzaid, o anteprojeto que elaborou. Segundo ele, o Código Civil brasileiro continuava dividido em duas grandes partes: a geral (constituída de três livros: "Das pessoas", "Das coisas" e "Dos fatos jurídicos") e a especial (integrada por cinco livros: "Direito das obrigações", "Da atividade negocial", "Direito das coisas", "Direito de familia" e "Direito das sucessões"). A unificação do direito privado se faz com a integração, no Código Civil, do livro "Da atividade negocial", onde se disciplinam a figura do empresário, as sociedades (que se dividem em sociedades não personificadas e sociedades personificadas) e num título final institutos complementares (o registro do comércio, o nome comercial, a preposição e a escrituração a que estão sujeitos os empresários e as sociedades comerciais). Por outro lado, os princípios gerais dos títulos de crédito e os contratos até então regidos por leis comerciais foram incluídos no livro concernente ao Direito das Obrigações. Fora do Código, como objeto de futuras leis complementares do Código Civil, ficaram matérias como títulos de crédito em espécie e falência.

Esse Anteprojeto foi publicado, em 1972, no Diário Oficial da União e em volume autônomo, para receber críticas e sugestões.

Em março de 1973, apresentou a Comissão novo texto, com as modificações resultantes de sua própria iniciativa e das sugestões e críticas recebidas; esșe trabalho, nesse mesmo ano e em 1974, foi publicado, sucessivamente, em volume próprio e no Diário Oficial da União. Em seguida, fez-se nova revisão, à vista de sugestões de seus próprios membros e de 
contribuições críticas que lhe foram encaminhadas, cujo resultado foi a redação final apresentada ao Ministério da Justiça em janeiro de 1975. Nesse mesmo ano, o Governo encaminhou ao Congresso Nacional esse Projeto de Código Civil.

$\mathrm{Na}$ exposição de motivos desse Projeto, destacaram-se as principais inovações nele contidas. Dentre elas, merecem realce as seguintes:

\section{A) Na parte geral:}

o capítulo dedicado aos direitos da personalidade, visando à sua salvaguarda, sob múltiplos aspectos, desde a proteção dispensada ao nome e à imagem até o direito de se dispor do próprio corpo para fins científicos ou altruísticos;

o novo tratamento dispensado às pessoas jurídicas, precisando-se a distinção entre as pessoas jurídicas de fins não econômicos (associações e fundações) e as de escopo econômico (sociedade simples e sociedade empresária);

- as regras disciplinadoras da vida associativa em geral, com disposições especiais sobre as causas e a forma de exclusão de associados e sobre a repressão do uso indevido da personalidade jurídica;

- a atualização da disciplina dos negócios jurídicos, com mais rigorosa determinação de sua constituição, de seus defeitos e de sua invalidade, e evitando-se os equívocos que decorrem do Código Civil vigente pela falta de clara distinção entre validade e eficácia;

- a disciplina da lesão enorme e a colocação, na Parte Geral, de capítulo com preceitos gerais sobre a representação legal e a voluntária; e

- a distinção entre decadência e prescrição, regulam-se uma e outra.

B) - Na parte especial:

I No direito das obrigações:

harmonizou-se a matéria relativa ao inadimplemento das obrigações com os artigos do Projeto que estabelecem novas diretrizes éticosociais no concernente à responsabilidade civil;

conferiu-se ao juiz poder moderado quanto às penalidades resultantes do inadimplemento contratual; 
disciplinou-se o contrato de adesão; solucionaram-se problemas resultantes do contrato de construção; deu-se novo tratamento ao contrato de seguro; incluiu-se, no Projeto, a disciplina da incorporação de edifícios em condomínio (o que se denominou "incorporação edilícia"), aperfeiçoando-a; regularam-se os contratos bancários;

- deu-se a disciplina geral dos títulos de crédito; ampliou-se o conceito de dano para abranger, inequivocamente, o dano moral;

- disciplinaram-se a venda com reserva de domínio (que é regulada atualmente no Código de Processo Civil) e o contrato com pessoa a nomear;

- aceitou-se a revalorização da moeda nas dívidas de valor, mas se proibiram cláusulas de correção monetária nos demais casos, com expressa ressalva, no entanto, da validade da estipulação de aumentos progressivos nos contratos de trato sucessivo;

- admitiu-se, na fixação das indenizações, que "se houver excessiva desproporçāo entre a gravidade da culpa e o dano, poderá o juiz reduzir, equitativamente, a indenização"; e

no capítulo referente à extinção do contrato, disciplinou-se a resolução por onerosidade excessiva.

II - No livro relativo à atividade negocial:

reviram-se os tipos tradicionais de sociedade, para configurá-los com melhor técnica;

fixaram-se os princípios que governam todas as formas de vida societária, em complementação à disciplina das associações estabelecida na Parte Geral;

instituiu-se a sociedade simples e deu-se tratamento minucioso à sociedade limitada;

- fixaram-se, em termos gerais, as normas caracterizadoras das sociedades anônimas e das cooperativas;

- disciplinou-se o tormentoso problema das sociedades ligadas;

- atualizaram-se as normas sobre o processo de transformação, incorporação, fusão e liquidação das sociedades; e 
- determinaram-se as notas distintivas do estabelecimento que representa o meio de ação da empresa.

\section{III - No direito das coisas:}

- incluíram-se na enumeração taxativa dos direitos reais a superfície e o direito do promitente comprador do imóvel;

- estabeleceu-se que o direito de propriedade deve ser exercido em consonância com suas finalidades econômicas e sociais, preservando-se, como disposto na legislação especial, a flora, a fauna, as belezas naturais e o equilíbrio ecológico, evitando-se a poluição do ar e das águas;

admitiu-se que, mediante justa indenização, poder-se-á privar o proprietário do imóvel reivindicando, se consistir este em extensa área que se encontre na posse ininterrupta e de boa-fé, por mais de cinco anos, de considerável número de pessoas, que nela hajam realizado obras e serviços considerados pelo juiz de interesse social e econômico relevante;

- reduziram-se os prazos do usucapião;

- disciplinou-se a propriedade fiduciária;

- atualizaram-se as normas concernentes à anticrese e à hipoteca; $\mathrm{e}$

- não se manteve o instituto da enfiteuse no que diz respeito aos imóveis particulares.

\section{No direito de família:}

- adotou-se, para a sua disciplina, a distinção entre direito pessoal de familia e direito patrimonial de família;

- reduziu-se o poder marital, estabelecendo-se que as questões essenciais são decididas em comum, sendo sempre necessária a colaboração da mulher na direção da sociedade conjugal; havendo divergência, prevalece a decisão do marido, mas a mulher pode recorrer ao juiz, desde que não se trate de matéria personalíssima;

o domicílio do casal passou a ser escolhido por ambos os cônjuges; e o exercício do pátrio poder compete tanto ao marido quanto à mulher;

deu-se nova disciplina à invalidade do casamento; 
- reconheceu-se à mulher o direito de retomar seu nome de solteira, se condenado o marido na ação de desquite;

deu-se nova disciplina à adoção, distingüindo-se a adoção plena da adoção restrita;

o regime legal de bens passou a ser o da comunhão parcial;

não se acolheu, como regime de bens típico, o regime dotal;

disciplinou-se novo regime de bens: o da participação final dos aquestos;

- alterou-se a disciplina do bem de familia para torná-lo capaz de realizar efetivamente a relevante função social a que se destina;

- introduziram-se modificações na disciplina da tutela e da curatela;

e

- transferiu-se para lei especial a disciplina das relações patrimoniais entre concubinos.

$\mathrm{V}$ No direito das sucessões:

- com as modificações no direito de família, fizeram-se alterações no direito sucessório, como, por exemplo, considerar o cônjuge como herdeiro necessário, tendo em vista a modificação do regime legal de bens;

- deu-se maior amparo aos filhos legítimos, aos quais caberão dois terços da herança cabível a cada um dos legítimos;

- disciplinou-se a situação sucessória do filho adotivo, conforme se trate de adoção plena ou de adoção restrita;

- simplificaram-se as formalidades do testamento, sem perda dos valores de certeza e segurança;

- admitiu-se que o testamento cerrado possa ser feito por outra pessoa, a rogo do testador;

- estabeleceu-se a suficiência de duas testemunhas contestes para a confirmação de testamento particular;

- reviu-se a disciplina do fideicomisso, prevendo-se a possibilidade de sua conversão em usufruto; e

- deu-se novo tratamento à arrecadação da herança jacente, bem como de sua vacância. 
Esse projeto tramitou na Câmara dos Deputados de 1975 a 1984, quando foi aprovado com várias modificações acolhidas pelo relator geral da Comissão Especial, resultantes principalmente de emendas (cujo número ascendeu a 1.063, embora a maioria afinal tenha sido rejeitada) analisadas pelos relatores parciais dessa mesma Comissão. Nessas alterações - e note-se que a Comissão Especial da Câmara dos Deputados ouviu sobre as emendas a Comissão que havia elaborado o Anteprojeto que se transformou no Projeto encaminhado ao Congresso pelo Executivo - levaram-se em conta, no direito de família, as alterações introduzidas pela Lei n. 6.515, de 1977, que em virtude da Emenda Constitucional n. 9, de 28 de junho de 1977, que admitiu a dissolubilidade do casamento disciplinou o divórcio e modificou vários dispositivos do Código Civil.

Atualmente, continua no Senado esse Projeto aprovado pela Câmara dos Deputados.

No final de agosto de 1989, o Senador Nelson Carneiro publicou seu parecer como membro da Comissão que examina o Projeto vindo da Câmara dos Deputados às emendas do Plenário sobre o livro referente ao direito de familia. $\mathrm{Na}$ introdução a esse parecer, adverte seu autor que ele foi concluído em junho de 1987, sendo necessário, portanto, reexaminar opiniões então expostas por causa das inovações trazidas pela Constituição de 5 de outuhro de 1988. 